\title{
COMMENTS
}

\section{THE PARAMETERS OF FEDERAL COMMON LAW: THE CASE OF TIME LIMITATIONS ON FEDERAL CAUSES OF ACTION}

\author{
DoNnA A. Boswell $\dagger$
}

\begin{abstract}
A far more pervasive influence on the orderly development of the law ... is the habit of mind with which judges and lawyers approach the decision which no precedent necessarily controls.*
\end{abstract}

\section{INTRODUCTION}

To note that the statutory schemes enacted by Congress have gaps in them is to restate a truism. ${ }^{1}$ Numerous details-ranging from seemingly minor concerns, such as an appropriate limitations period, ${ }^{2}$ to major issues such as the definition of a "stationary source" of pollution, ${ }^{3}$-are "missing" from federal statutes. These missing details inevitably give rise to lawsuits when the statutory scheme is implemented.4

† B.A. 1972, M.A. 1974, Wake Forest University; Ph.D. 1977, The Pennsylvania State University; J.D. Candidate 1989, University of Pennsylvania.

* Stone, The Common Law in the United States, 50 Harv. L. Rev. 4, 9 (1936).

' See Friendly, The Gap in Lawmaking-Judges Who Can't and Legislatures Who Won't, 63 Colum. L. Rev. 787, 792 (1963) [hereinafter Friendly, The Gap in Lawmaking].

${ }^{2}$ See, e.g., Securities Exchange Act of 1934, 15 U.S.C. \$§ 78a-78kk (1982 \& Supp. IV 1986) (no statute of limitations specified); Racketeer Influenced and Corrupt Organizations Act, 18 U.S.C. $\S \S 1961-68$ (1982 \& Supp. IV 1986) (same); Fair Labor Standards Act of 1938, 29 U.S.C. $\$ \S 201-19$ (1982 \& Supp. III 1985) (same); the Civil Rights Acts, 42 U.S.C. $\$ \S 1981-88$ (1982) (same); Communications Act of 1934, 47 U.S.C. $\S \S 151-610$ (1982 \& Supp. III 1985) (same); Military Selective Service Act, 50 U.S.C. $\$ \S 460-73$ (1982) (same).

${ }^{3}$ See, e.g., Clean Air Act Amendments of 1977, Pub. L. No. 95-95, 91 Stat. 685, 697 , (codified at 42 U.S.C. $\$ 7411$ (1982)) (no definition of "stationary source" provided).

4 This Comment will focus on the case of "missing" federal statutes of limitations. Time limitations differ from other statutory gaps in that they have a history of being independently filled by reference to state "procedural" statutes. However, this differ- 
Because there is no mechanism, short of enacting an amending statute, for Congress to add or change an element of the statute, ${ }^{5}$ what may have begun as a congressional omission necessarily becomes part of the disputes that courts must resolve.

Whether one regards these gaps as flaws produced by the inadequacy of the legislative process, ${ }^{6}$ or as an inevitability of legislating in a complex society, ${ }^{7}$ these statutory interstices must be filled if the statutory scheme is to provide citizens with the rights and services envisioned by its enactors. And because the judiciary is charged with deciding the cases and controversies federal statutory schemes engender, the job of filling in the gaps necessarily falls to the courts. As Justice Stevens recently wrote for the Supreme Court: "Inevitably our resolution of cases or controversies requires us to close interstices in federal law from time to time . . . .8 Although the Court may be reluctant to declare a specific rule, ${ }^{9}$ to decide the case is to create a policy to fill the gap. ${ }^{10}$ In

ence serves primarily to sharpen the issues a court must consider in making federal common law. See infra notes 95-112 and accompanying text.

s Although the Sherman Antitrust Act, ch. 647, § 7, 26 Stat. 209 (1890), 15 U.S.C. $\S 15$ (1982), was enacted without a statute of limitations, Congress amended it on July 7, 1955, to add a four year time bar. See Ch. 283, § 4B, 69 Stat. 282, 282-83, (codified at 15 U.S.C. $\S 15$ (b) (1982)). Limitations have also been enacted for copyright actions, see 17 U.S.C. $§ 507$ (1982), and for patent actions, see 35 U.S.C. $§ 286$ (1982).

- See, e.g., Friendly, The Gap in Lawmaking, supra note 1, at 792 ("What I do lament is that the legislator has diminished the role of the judge by occupying vast fields and then has failed to keep them ploughed."); Note, Disparities in Time Limitations on Federal Causes of Action, 49 YaLE L.J. 738, 738 (1940) (attributing the lack of a limitation period to "legislative inertia").

7 See, e.g., United States v. Little Lake Misere Land Co., 412 U.S. 580, 593 (1973) ("TT]he inevitable incompleteness presented by all legislation means that interstitial federal lawmaking is a basic responsibility of the federal courts."); Friendly, In Praise of Erie-And of the New Federal Common Law, 39 N.Y.U. L. REv. 383, 419 (1964) [hereinafter Friendly, In Praise of Erie] ("One of the beauties of [common lawmaking by federal judges] is that it permits overworked federal legislators . . . so easily to transfer a part of their load to federal judges, who have time for reflection and freedom from fear as to tenure.....").

8 West v. Conrail, 107 S. Ct. 1538, 1542 (1987).

9 In rejecting a party's request that the Court devise a uniform time limitation to close the statutory gap, Justice Stewart called the creation of such a rule a "bald . . form of judicial innovation." UAW v. Hoosier Cardinal Corp., 383 U.S. 696, 701 (1966).

${ }^{10}$ In Occidental Life Ins. Co. v. EEOC, 432 U.S. 355, 366-72 (1977), the Court refused to fill the gap with the State's limitation period, deciding instead that there was no time bar on plaintiff's claim. While the Court did not supply a limitations period, the decision, nonetheless, established a policy for the administration of EEOC lawsuits in the state of California. Presumably, the only way the Court could avoid "declaring" such a policy is to refuse to grant certiorari, thus allowing the various solutions jerrybuilt by the lower courts to implement incomplete statutes. Refusing to hear a case or apply a statute, however, is, as is evident in Judge Easterbrook's approach, a very explicit policy statement. See Easterbrook, Statutes' Domains, 50 U. GHI. L. Rev. 533, 
filling these gaps the courts create federal common law, ${ }^{11}$ which becomes an integral part of the statutory scheme as it is implemented.

The Court traditionally has approached the task of making federal common law as though it were challenged to tread a narrow path between unacceptable alternatives. The mainstream of judicial analysis has not generally favored the notion of an unfettered judiciary "legislating" in the interstices of congressional enactments. ${ }^{12}$ The Court, nevertheless, is acutely aware that it must fill the gaps or it will be unable to adjudicate the cases arising under these laws. ${ }^{13}$ In effect, interstitial lawmaking requires the Court to walk the line between shirking its constitutionally mandated task of adjudicating cases and controversies, and usurping the legislative power of the Congress by declaring its own rules for deciding disputes.

The constraints that channel the Court's federal common lawmaking activity have been the subject of considerable debate. ${ }^{14}$ Is this

534 (1983).

II The distinction between federal common law making and statutory construction is a fine one. Traditionally, the term "federal common law" describes what a court has created when filling an actual gap in a statutory scheme, as well as a court's creation of law on the basis of a jurisdictional grant, such as admiralty law. Statutory construction, on the other hand, is the result of interpreting the ambiguous words of a statute, such as the Sherman Act, so that the congressional scheme can be implemented. See Westen \& Lehman, Is There Life for Erie after the Death of Diversity?, 78 MICH. L. REv. $311,331-36$ (1980).

12 See Texas Indus., Inc. v. Radcliff Materials, Inc., 451 U.S. 630, 639 (1981) ("Nothing in these statutes refers to [the matter in question], and if such a right exists it must be by implication. Our focus, as it is in any case involving the implication of a right of action, is on the intent of Congress."); Llewellyn, Remarks on the Theory of Appellate Decision and the Rules or Cannons About How Statutes Are to be Construed, 3 VAND. L. Rev. 395, 400 (1950) (commenting on the Formalists' insistence on precise language). However, Westen and Lehman note that:

[T]o say that Congress's authority to legislate is final does not mean it is exclusive. The federal courts possess a competence to "make" law by virtue of their constitutional authority to say what the law is. Article III vests them with the "Judicial Power," the power to interpret the law in the course of resolving individual "cases and controversies." This power to interpret the actions and silences of Congress-to "say what the law is"-is an obvious source of lawmaking power.

Westen \& Lehman, supra note 11 , at 326.

${ }_{13}$ See West v. Conrail, 107 S. Ct. 1538, 1542 (1987); United States v. Little Lake Misere Land Co., 412 U.S. 580, 593 (1973); Clearfield Trust Co. v. United States, 318 U.S. 363, 367 (1943).

14 See Field, Sources of Law: The Scope of Federal Common Law, 99 Harv. L. Rev. 881, 888 (1986); Merrill, The Common Law Powers of Federal Courts, 52 U. CHI. L. Rev. 1, 1-7 (1985). At the metatheoretical level this is the same debate that characterizes contemporary analyses of statutory interpretation. See Easterbrook, The Supreme Court 1983 Term-Foreword: The Court and the Economic System, 98 HARv. L. REv. 4, 4-18 (1984); Eskridge, Dynamic Statutory Interpretation, 135 U. PA. L. Rev. 1479, 1479 (1987). Much of the debate focuses on the dispute between Critical Legal Studies' proponents, and those who would reconstruct a legislature's 
power as limitless as proponents of Critical Legal Studies would imply ${ }^{15} \mathrm{Or}$, is it firmly grounded in the positive texts and grants of authority to which the formalists appeal ? $^{16}$ This Comment argues that one of the most important influences on common law making (as on statutory construction) is judges' meta-legal orientations toward the judging task, ${ }^{17}$ and moreover, that these meta-legal orientations give shape and substance to the common law that is made. The main thrust of the Comment will be to illustrate the implications of this type of influence on developments in the law by analyzing the opinions produced in a recent case in which the Supreme Court stated a new common law time limitation for a federal statutory cause of action: $:^{18}$

Part I examines the problem of interstitial lawmaking from a traditional federal common law perspective and introduces the metalegal concepts that are used in the analysis presented in Part III. Part II discusses the statutory problem and the opinions in the exemplary

original intention. See generally Brest, The Misconceived Quest for the Original Understanding, 60 B.U.L. REv. 204, 205-09 (1980) (rejecting literal interpretation of the Constitution as an exercise in futility); Posner, Statutory Interpretation-in the Classroom and in the Courtroom, 50 U. GHI. L. REv. 800, 817-822 (1983) (arguing that a judge should reconstruct the legislator's intent).

${ }_{15}$ Without ... a guiding vision, legal reasoning seems condemned to a game of easy analogies. It will always be possible to find, retrospectively, more or less convincing ways to make a set of distinctions, or failures to distinguish, look credible. . . . Because everything can be defended, nothing can; the analogy mongering must be brought to a halt.

R. Unger, The Critical Legal Studies Movement 8 (1986).

${ }_{18}^{16}$ See Ex parte Collett, 337 U.S. 55, 61 (1949) ("[T]here is no need to refer to the legislative history where the statutory language is clear."). As the traditional canon of statutory construction avers: "A statute cannot go beyond its text." K. LLEWELLYN, The Common Law Tradition: Deciding Appeals 522 (1960); see also 2A Sutherland, Statutes and Statutory Construction, $\$ 45.05$ (4th ed. 1984) ("legislative will governs decisions on the construction of statutes"); Frankfurter, Some Reflections on the Reading of Statutes, 47 Colum. L. REv. 527, 533 (1947) ("A judge must not rewrite a statute, neither to enlarge nor contract it.").

17 The label "meta-legal orientation" refers to the set of beliefs and values that judges bring to bear in trying to understand a particular case. See generally Fiss, The Supreme Court 1978 Term-Foreword: The Forms of Justice, 93 HaRv. L. REv. 1, 50-58 (1979) (discussing the normative political and moral constraints within legal communities). While some elements of this meta-legal framework are invoked intentionally by the decisionmaker (e.g., adherence to precedent, cannons of statutory construction, and the like,) others manifest each judge's tacit knowledge of the world that constitutes the indispensible, if unseen, foundation of personal acting and knowing. See M. Polanyi, The Tacit Dimension 21-25 (1967) (arguing that knowledge is structured by a prior, tacit framework for perceiving and thinking about problems). See generally H. GADAMER, TRUTH AND METHOD 269-74 (1975) (discussing the "horizon" of each person's understanding).

${ }_{18}$ Agency Holding Corp. v. Malley-Duff \& Assocs., Inc., 107 S. Ct. 2759 (1987). The statutory cause of action is the private damages remedy under the Racketeer Influenced and Corrupt Organizations Act (RICO), 16 U.S.C. § 1964(c) (1982). 
case, and Part III develops the implications of the meta-legal orientations evident in the Justices' opinions.

\section{INTERSTITIAL LAWMAKING}

The difficulty in understanding federal common law commences with its very existence. Every first year law student learns that Justice Brandeis told us conclusively in Erie that "[t]here is no federal general common law." 19 The federal common law that we are concerned with, however, is not something that has evolved as an exception to Erie. To the contrary, the Brandeis proposition has been reaffirmed by the Court within the past decade. ${ }^{20}$ Federal common law decisions coexisted with Erie; ${ }^{21}$ that decision did not solve, purport to solve, or eliminate the problem of how to fill the interstices of federal statutes.

\section{A. Defining Federal Common Law}

To reduce confusion, federal common law is sometimes called "specialized federal common law"22 or, in recognition of the change wrought by Erie, the "new federal common law."23 Judge Friendly explained that "Erie led to the emergence of a federal decisional law in areas of national concern that is truly uniform because, under the supremacy clause, it is binding in every forum ...."24 The crucial distinction in deciding whether state law forms the basis of the federal court's decision, or whether federal common law applies, is the source of the right sued upon. That is, does the question depend upon a right granted by state law (in which case a federal court is governed by Erie and its progeny)? Or, does the right stem from a federal statute or the Constitution (in which case, the federal court is empowered to make federal common law)?

Even this distinction does not remove ambiguity, because of vague preconceptions about a mythical "body" of common law, and its rela-

19 Erie R.R. v. Tompkins, 304 U.S. 64, 78 (1938).

${ }^{20}$ See, e.g., City of Milwaukee v. Illinois, 451 U.S. 304, 312 (1981) ("Federal courts, unlike state courts, are not general common-law courts and do not possess a general power to develop and apply their own rules of decision.").

21 See, e.g., Hinderlider v. La Plata River \& Cherry Creek Ditch Co., 304 U.S. 92, 110 (1938) (ruling that federal common law governed a dispute about apportionment of an interstate stream). This case was decided by the Supreme Court on the same day as Erie.

22 See Friendly, In Praise of Erie, supra note 7, at 405.

${ }^{23}$ See id. at 421. Judge Friendly maintained that Justice Brandeis's Erie opinion, by "insisting that federal courts defer to the states on matters outside the states' grant of power to the nation, . . . cleared the way for [a] truly uniform federal common law on issues of national concern . . . " Id. at 384.

${ }^{24} I d$. at 405. 
tion to the decisions that judges render in filling statutory interstices. As Professor Jay observes:

It brings to mind the image of a body of law, similar to the way in which courts once referred to the English common law as a corpus of specific rules and principles. Usually, however, the "common law" is taken by us to be a convenient expression for the process by which judges make binding judgments based on nonstatutory rules. ${ }^{25}$

Professor Jay notes that it is the process of making common law that continues to be significant; contemporary jurisprudence has rejected the notion that there is a "seamless web of law" that the common law judges attempt to discover.$^{26}$ Nevertheless, one of the important issues to be resolved in understanding the process by which federal common law is made concerns the extent to which the perceived omnipresence of such a hypothetical body of law provides a philosophical foundation for contemporary decisions.

Recent commentators have favored a definition of federal common law that more clearly acknowledges its relation to statutory interpretation. ${ }^{27}$ Westen and Lehman, for example, maintain that

[t]he difference between "common law" and "statutory interpretation" is a difference in emphasis rather than a difference in kind. The more definite and explicit the prevailing legislative policy, the more likely a court will describe its lawmaking as statutory interpretation; the less precise and

${ }^{25}$ Jay, Origins of Federal Common Law: Part One, 133 U. PA. L. REv. 1003, 1006-07 (1985).

${ }^{28}$ Justice Holmes has criticized this view:

Books written about any branch of the common law treat it as a unit, cite cases from this Court, from the Circuit Courts of Appeals, from the State Courts, from England and the Colonies of England indiscriminately, and criticise them as right or wrong according to the writer's notions of a single theory. It is very hard to resist the impression that there is one august corpus .... . But there is no such body of law. The fallacy and illusion that I think exist consist in supposing that there is this outside thing to be found. Law is a word used with different meanings, but law ... does not exist without some definite authority behind it. The common law so far as it is enforced in a State, ... is not the common law generally but the law of that State existing by the authority of that State . . . .

Black \& White Taxicab \& Transfer Co. v. Brown \& Yellow Taxicab \& Transfer Co., 276 U.S. 518, 533 (1928) (Holmes, J, dissenting). ing text.

${ }_{27}$ See Field, supra note 14 , at 890 \& n.31; see supra notes $11-14$ and accompany- 
less explicit the perceived legislative policy, the more likely a court will speak of common law. ${ }^{28}$

In acknowledging the relation between federal common law and statutory construction, contemporary analyses emphasize the specific statutory scheme that provides the textual context within which the court creates common law. Thrusting the statutory scheme to the fore tends automatically to reduce the significance of an encompassing hypothetical body of common law.

One of the more frequently cited definitions of federal common law is that offered by Professors Hart and Wechsler: "[F]ederal common law . . . refer[s] generally to federal rules of decision where the authority for a federal rule is not explicitly or clearly found in federal statutory or constitutional command."20 This definition identifies four major quasi-objective characteristics of federal common law.

First, the absence of "commands" is essential to the concept of judge-made law. As the Court has indicated, "[ $t]$ here will often be no specific federal legislation governing a particular transaction ....; here, for example, no provision . . . guides us . . . in interpreting . . . agreements under the Act. But silence on that score in federal legislation is no reason for limiting the reach of federal law . . . ."30 In making common law the court is generating its own rules of decision, within the parameters of the statutory scheme that defines the rights of the parties. ${ }^{31}$

Second, the rule of decision fashioned in this way is federal law. Like statutes enacted by Congress, federal common law is binding on the state courts that adjudicate analogous issues under their concurrent jurisdiction. Thus, when the Court borrows a state rule, or an international convention, ${ }^{32}$ to make federal common law, it is transforming that rule into federal law. ${ }^{33}$

${ }^{28}$ Westen \& Lehman, supra note 11, at 332; see also P. Bator, P. Mishin, D. Shapiro \& H. Wechsler, Hart \& Wechsler's The Federal Courts aNd the FEDERAL SySTEM 770 (2d ed. 1973) [hereinafter HART \& WechSLER] ("Statutory interpretation shades into judicial lawmaking on a spectrum, as specific evidence of legislative advertence to the issue at hand attenuates.").

28 HART \& WECHSLER, supra note 28, at 770.

${ }^{30}$ United States v. Little Lake Misere Land Co., 412 U.S. 580, 593 (1973).

${ }^{31}$ As Justice Holmes acknowledged: "I recognize without hesitation that judges do and must legislate, but they can do so only interstitially; they are confined from molar to molecular motions." Southern Pac. Co. v. Jensen, 244 U.S. 205, 221 (1917) (Holmes, J., dissenting).

32 See, e.g., Banco Nacional de Cuba v. Sabbatino, 376 U.S. 398, $436-37$ (1964) (incorporating the international "act of state" doctrine to resolve a dispute between Cuba and a corporation principally owned by American nationals). States:

${ }^{33}$ As Justice Frankfurter noted in Board of County Commissioners v. United

Since the origin of the right to be enforced is the Treaty, plainly whatever 
Third, by implication federal common law should be distinguished from statutory interpretation by the federal judiciary that involves state-created rights. Some federal statutes, for example, explicitly incorporate state law, such that state law operates by federal authority ${ }^{34}$ In such cases, the cause of action is a federal one, but in applying the state provision, the federal court is bound by the decisional law of the highest court of the state, and the federal court's interpretation of the state provision is not binding on the courts of the state.

Finally, while Professors Hart and Wechsler call attention to the lack of a constitutional command, the notion of lawmaking in a constitutional context should be carefully distinguished from federal common law. ${ }^{35}$ Federal common law can be reversed by congressional enactment. ${ }^{36}$ If the Court fills a statutory gap, or renders an interpretation of which Congress disapproves, Congress can amend the statute, and the new provision, rather than Court precedent, is binding on future parties. ${ }^{37}$ On the other hand, when the Court interprets the Constitution, the resulting law cannot be overturned by Congress without resorting to the cumbersome constitutional amendment process. ${ }^{38}$ Con-

rule we fashion ... does not owe its authority to the law-making agencies of [the State]. And so the concrete problem is to determine the material out of which the judicial rule . . . should be formulated.

... [S]tate law has been absorbed, as it were, as the governing federal rule not because state law was the source of the right but because recognition of state interests was not deemed inconsistent with federal policy.

Board of County Comm'rs v. United States, 308 U.S. 343, 349-52 (1939) (citation omitted).

${ }^{34}$ The Federal Tort Claims Act, 28 U.S.C. $\S 1346(\mathrm{~b})$ (1982), indicates that the "law of the place where the act or omission occurred" controls the dispute, and the Social Security Act, 42 U.S.C. $§ 416(h)(1)(A)(1982)$, defines a federal exemption provision by referring to the state law definition of "wife, husband, widow, or widower" of an insured person.

${ }^{36}$ See Monaghan, The Supreme Court, 1974 Term-Foreword: Constitutional Common Law, 89 HaRv. L. REv. 1, 30 (1975) (distinguishing constitutional common law from constitutional interpretation). But see Merrill, supra note 14, at 6 (arguing that "distinguishing constitutional law from federal common law at the definitional stage begs some important questions").

${ }^{36}$ Westen and Lehman note that "[w]ithin areas of nonconstitutional law, . . . the federal courts . . . are subordinate to Congress and the other institutions possessing final lawmaking power." Westen \& Lehman, supra note 11, at 329.

37 See, e.g., Rehabilitation Act Amendments of 1986, Pub. L. No. 99-506, $\S 1003,100$ Stat. 1807, 1845, overruling Atascadero State Hosp. v. Scanlon, 473 U.S. 234, 246-47 (acceptance of federal funds under the Rehabilitation Act does not constitute a waiver of eleventh amendment sovereign immunity without clear congressional provision for such a waiver), reh'g denied, 473 U.S. 926 (1985).

${ }^{38}$ See Oregon v. Mitchell, 400 U.S. 112, 117-18 (1970) (adjudicating the constitutionality of the Voting Rights Act Amendments of 1970), overruled, U.S. Const. amend. XXVI. The binding effect of the Court's constitutional decisions results from 
stitutional precedents are applicable to future disputes until the Court changes its interpretation of the provision.

All four of these criteria are met by the situation in which a federal statute lacks a time limitation for bringing a private cause of action. ${ }^{39}$ Typically, Congress has been silent on the question of limitations. ${ }^{40}$ There are no constitutional prescriptions or proscriptions regarding time bars, ${ }^{41}$ no state-created right is implicated, ${ }^{42}$ and a federal judge-made time limitation is recognized as an integral part of the federal statutory scheme as implemented in state as well as federal courts. $^{43}$

the article III grant of authority to hear cases arising under the Constitution, interpreted as a basis for judicial review:

As part of their power to 'say what the law is,' the federal courts possess (by their own determination) the final power to say what the Constitution means. [T]he federal courts possess final rulemaking power over constitutional law-or, more accurately, over what the federal courts declare to be constitutional law.

Westen \& Lehman, supra note 11, at 328-29 (footnotes omitted); see Marbury v. Madison, 5 U.S. (1 Cranch) 137, 178-80 (1803).

${ }^{38}$ The situation is slightly different when Congress has not specifically provided a private cause of action, but the courts have implied one. For example, the private action for fraud under $\S 10$ (b) of the Securities Exchange Act of 1934, ch. 404, tit. I, $\S 10(b), 48$ Stat. 891 (codified at 15 U.S.C. $\S 78(j)$ (1982)), is a product of the Court's interpretation of the statute rather than a specific statutory provision. Compare J.I. Case Co. v. Borak, 377 U.S. 426, 430-31 (1964) and Note, Implied Causes of Action: A Product of Statutory Construction or the Federal Common Law Power?, 51 U. CoLo. L. REv. 355, 357-58 (1980) with Touche Ross \& Co. v. Redington, 422 U.S. 560,577 (1979). When the cause of action arguably arises under federal common law, it is somewhat incongruous to argue that Congress "omitted" to state a time limitation. Accordingly, the present analysis is restricted to situations in which Congress has explicitly provided a private remedy, but has not indicated a time bar for that remedy.

${ }^{10}$ See, e.g., DelCostello v. International Bhd. of Teamsters, 462 U.S. 151, 158-59 (1983) (noting that congressional silence as to a time limitation does not mean that there is no time bar); UAW v. Hoosier Cardinal Corp., 383 U.S. 696, 704-05 (1966) (same).

41 However, constitutional questions may be raised when an applicable state limitations period is too short to permit vindication of a federally-created right. See, e.g., Caldwell v. Alabama Dry Dock \& Shipbuilding Co., 161 F.2d 83, 85-86 (5th Cir.) (holding a state statute of limitations inapplicable, on supremacy clause grounds, to an action brought under the Fair Labor Standards Act), cert. denied, 332 U.S. 759 (1947); Republic Pictures Corp. v. Kappler, 151 F.2d 543, 547 (8th Cir. 1945) (same, on equal protection grounds), affd per curiam, 327 U.S. 757 (1946).

42 Historically, state general limitations statutes do not concern the rights of parties; they are rules governing the availability of state forums for vindicating rights granted by statutory or common law authority. See infra notes 95-98 and accompanying text.

${ }^{43}$ For example, the federal common law rule provided by the Court in Wilson v. Garcia, 471 U.S. 261, 270, 280 (1985), concerning an appropriate statute of limitations for $\S 1983$ claims, has been accepted in the following state cases: Vanaman v. Palmer, 506 A.2d 190, 192 (Del. Super. Ct. 1986) (Wilson is controlling in characterizing the nature of plaintiff's claim for purposes of borrowing state statutes of limitation); Henderson v State, 110 Idaho 308, 311, 715 P.2d 978, 981 (1986) (same), cert. denied, 106 


\section{B. The Court's Approach}

A two-fold inquiry characterizes the Court's customary assessment of whether or not federal common law governs an issue: a "power" analysis, and a "discretion" analysis. ${ }^{44}$

\section{The Power Analysis}

This phase of the inquiry concerns whether or not the Court has authority to make common law regarding the issue at bar. The Court considers two sets of factors the Court considers in evaluating the scope of its authority to make common law: 1) constitutional requirements (including individual rights and liberties, separation of powers, and federalism concerns) and 2) congressional guidelines (including express as well as implicit requirements of the substantive policy articulated in the statute). ${ }^{45}$

\section{a. Constitutional Guidelines}

One way to interpret the constitutional guidelines for federal common law making raises the possibility that the Court's authority extends as far as the potential powers granted to it in the Constitution. In this view, the only limits on the Court's authority would be the due process and substantive rights of individuals, tenth and eleventh amendment limitations on incursions into the states' domains, and the separation of judicial, executive, and legislative powers designed to prevent the concentrations of power that increase the risk of tyranny.

The separation of powers issue underlies the judiciary's traditional proscription of "legislating" by courts; its more contemporary manifestation is evident in some Justices' concern about Congress delegating its

S. Ct. 3283 (1986); Frisby v. Board of Educ., 707 S.W.2d 359, 362 (Ky. Ct. App. 1986) (same); Fuchilla v. Layman, 210 N.J. Super. 574, 583-84, 510 A.2d 281, 286 (1986) (same), aff d, No. A-122 (N.J. Feb. 8, 1988) (LEXIS, States library, N.J. file); Walker v. Maruffi, 737 P.2d 544, 549 (N.M. Ct. App. 1987) (same); Ziccardi v. Commonwealth, 527 A.2d 183, 185-87 ( $\mathrm{Pa}$. Commw. Ct. 1987) (adopting the rule of Wilson but concluding that it does not apply retroactively). But see Felder v. Casey, 139 Wis. 2 d 614, 627-28, 408 N.W.2d 19, 25, cert. granted, 108 S. Ct. 326 (1987) (finding state "notice of claims" statute applicable to $\$ 1983$ actions; dissent by Judge Abrahamson, 139 Wis. $2 \mathrm{~d}$ at $631-32,408$ N.W.2d at 27, is based on Wilson). Felder may be inconsistent with the more recent decision in West v. Conrail, 107 S. Ct. 1538, 1542 (1987) (holding that only what is necessary to fill the federal statutory gap is "borrowed" from state law).

14 See Field, supra note 14, at 885-86.

45 Cf. HART \& WECHSLER, supra note 28, at 767-68 (discussing four different assumptions regarding the authoritativeness of state law operating within the interstices of congressional statutes). 
legislative power to administrative agencies. One of then-Justice Rehnquist's concerns in Industrial Union Department v. American Petroleum Institute ("Benzene"), ${ }^{\mathbf{4}}$ for example, is that when broad legislative authority is delegated to agencies, and the Court is called upon to decide disputes that arise under agency rules, there may be little indication of how Congress itself would have stated the legal rule. ${ }^{47}$ Thus, in order to adjudicate the parties' dispute the Court would be required to make policy-to "legislate"-without explicit congressional guidance.

Serious federalism concerns would be raised if the scope of federal common law extended to the limits of the powers granted to Congress under the Constitution. ${ }^{48}$ However, such a view may be supported by the Court's holding in Erie. Arguably, Swift v. Tyson "was unconstitutional, because it accorded the federal courts more extensive authority to make law than Congress itself possessed." 49 By implication, federal common law making would be constitutional so long as it did not exceed Congress's article I powers. The Court has not taken this view of its authority under the Constitution. ${ }^{50}$

More typically, the federalism argument is not predicated on the explicit provisions of the Constitution, so much as on the federalist structure of our government. ${ }^{51}$ This view is inspired by language in Justice Brandeis's Erie opinion, asserting: "Congress has no power to declare substantive rules of common law .... And no clause in the Constitution purports to confer such a power upon the federal courts." 12 The animating principle of this view is that the federal government-the legislative, executive, and judicial branches-is a government of limited, delegated powers. Because the state governments' "reserved" powers are plenary, the presumption is that federal courts should look to the state law for guidance in the absence of specific con-

48448 U.S. 607 (1980).

47 See id. at 672 (Rehnquist, J., concurring in the judgment); see also Chevron U.S.A. Inc. v. Natural Resources Defense Council, Inc., 467 U.S. 837, 843-44 (1984) (holding that in absence of specific congressional statements concerning a legal issue, the matter is considered delegated to agency discretion by law, and the court should defer to the agency's construction).

18 See Field, supra note 14, at 923-27.

49 Westen \& Lehman, supra note 11 , at 338.

so See Texas Indus., Inc. v. Radcliff Materials, Inc., 451 U.S. 630, 641 (1981) ("[T] $T$ he existence of congressional authority under Art. I [does not] mean that federal courts are free to develop a common law to govern those areas until Congress acts.").

s1 For an extreme example, see Clark, Federal Procedural Reform and States' Rights; To a More Perfect Union, 40 TEX. L. REv. 211, 220-21 (1961), who maintains that the conclusion of the post-Erie "outcome-determinative" test (which renders all federal common law making illegitimate), is logical but is not reasonable. See also Merrill, supra note 14, at 13-19 (discussing federalism as a limitation on common lawmaking power of the federal courts).

${ }^{62}$ Erie, 304 U.S. at 78. 
gressional pronouncements. ${ }^{63}$ Thus, a structural analysis would require federal courts to examine state law when interpreting particular provisions of congressional statutes or when supplying missing fragments.

By interpreting the doctrine of enumerated powers as if it were independent of the necessary and proper clause, ${ }^{54}$ however, this view oversimplifies federalism questions. Why doesn't the Court's interpretation of a congressional enactment owe its first allegiance to the policy expressed in the statute? Once it is determined that the subject matter is within congressional authority, the necessary and proper clause would indicate that Congress can employ necessary and proper means of effectuating the policy. As Professor Jay notes, the notion of the Court's limited jurisdiction, in and of itself, cannot account for the restriction on the federal courts' common law-making powers:

[T] say that federal powers are derived from the concessions of sovereign states does not explicate the [question]. Federal courts may be of limited jurisdiction in the same sense that all federal authority is in theory specially delegated. But why are they not 'general common-law courts,' at least with respect to any subject potentially within federal legislative competence? ${ }^{85}$

This analysis suggests that the underlying rationale for deferring to state law depends on beliefs about the dynamics of the relationship between national and state governments that are not reflected in either the Constitution or the general structure of our government.

\section{b. Congressional Guidelines}

Congressional authority for the Court to make common law is sometimes explicitly granted. For example, Rule 501 of the Federal Rules of Evidence has been interpreted as an express delegation of authority for the Court to fashion a common law of testimonial privilege. ${ }^{\text {Bb }}$ Rule 501 provides that in federal question cases, "the privilege of a witness, person, government, State, or political subdivision thereof shall be governed by the principles of the common law as they may be

${ }^{53}$ See, e.g., Merrill, supra note 14, at 36-39 (discussing the circumstances under which it is legitimate for federal courts to "preempt" state law by making federal common law).

34 U.S. ConST. art. I, $\S 8$ ("The Congress shall have Power . . . To make all Laws which shall be necessary and proper for carrying into Execution the foregoing Powers, and all other Powers vested by this Constitution in the Government of the United States, or in any Department or Officer thereof.").

ss Jay, supra note 25, at 1004-05.

so See Merrill, supra note 14, at 42 \& n.183. 
interpreted by the courts of the United States in the light of reason and experience." ${ }^{957}$ Similarly, in Wilson v. Garcia, ${ }^{58}$ Justice Stevens may have found statutory instructions for ascertaining a statute of limitations for section 1983 actions. ${ }^{50}$ The Court referred to the section 1988 mandate that in cases where the laws of the United States were "deficient in the provisions necessary to furnish suitable remedies,"60 civil rights claims should be adjudicated by consulting "the common law, as modified and changed by the constitution and statutes of the State wherein the court having jurisdiction of such civil or criminal cause is held . . . ."61 When Congress provides such direction, it not only acknowledges its awareness that the Court will need to make federal common law in implementing the scheme, but provides some guidelines regarding the parameters of that common law.

Such explicit provision by Congress, however, is rather rare. More often, Congress does not provide instructions concerning how the Court is to fill statutory gaps. In such cases, the Court may infer from the statutory scheme that it is empowered to create common law. Accordingly, in United States $v$. Kimbell Foods, Inc. ${ }^{62}$ the Court held that the federal policy interests expressed in the Small Business Administration and Farmers' Home Administration Acts warranted creating a federal rule governing the priority of liens under those Acts. ${ }^{63}$ Moreover, the policy interests served by a statute, and what these might portend for the Court's authority, need not be found in statutory language or explicit statements by members of Congress. In Textile Workers Union v. Lincoln Mills, ${ }^{\text {b4 }}$ the Court reasoned on the basis of the legislature's jurisdictional grant and the general "purpose" of section 301 of the Labor Management Relations Act of $1947,{ }^{65}$ that Congress had directed it to make common law. ${ }^{68}$

s7 FED. R. Evid. 501.

88471 U.S. 261, 267 (1985).

69 See infra note 189.

${ }^{60} 42$ U.S.C. § 1988 (1982). The initial inquiry, as Justice Stevens notes, is to adjudicate the claim in "conformity with the laws of the United States, so far as such laws are suitable." Id. As the Court notes, "This mandate implies that resort to state law-the second step in the process-should not be undertaken before principles of federal law are exhausted." Wilson, 471 U.S. at 268.

${ }^{61} 42$ U.S.C. $\S 1988$ (1982).

62440 U.S. 715 (1979).

6s See id. at 726 .

64 353 U.S. 448 (1957).

${ }^{65}$ Ch. 120 , title III, $\S 301,61$ Stat. 136, 156 (codified at 29 U.S.C. $\S 185$ (1982)).

${ }^{68}$ See Lincoln Mills, 353 U.S. at 456. 


\section{The Discretion Analysis}

Once the Court has determined that it has the authority to fill the gap, the second prong of the Court's inquiry, the "discretion" prong, ${ }^{67}$ is used to select a rule of decision to fill the statutory gap. The Court's conservative assessment of its power, as well as the frequency with which it has found state law to be a convenient mechanism for implementing federal policy, suggest that the Court views common law making as a practical necessity-something that is a tangential requirement of fulfilling its constitutionally mandated duties. As Professor Mishkin observed:

At the very least, effective Constitutionalism requires recognition of power in the federal courts to declare, as a matter of common law or "judicial legislation," rules which may be necessary to fill in interstitially or otherwise effectuate the statutory patterns enacted in the large by Congress. In other words, it must mean recognition of federal judicial competence to declare the governing law in an area comprising issues substantially related to an established program of government operation. ${ }^{68}$

In keeping with the Court's conservative view that it does not use its discretion to engage in "bald . . f form[s] of judicial innovation," the Court has customarily drawn on: 1) its understanding of the statute or federal policy it is interpreting.70 ${ }^{7}$ ) precedents set by the Court in previous cases; ${ }^{71}$ and 3 ) the states' interest in the subject matter. ${ }^{72}$

${ }^{67}$ See Kimbell Foods, 440 U.S. at 727-29 (discussing the factors governing the Court's choice of a rule of decision in making federal common law).

${ }_{68}$ Mishkin, The Variousness of "Federal Law": Competence and Discretion in the Choice of National and State Rules for Decision, 105 U. PA. L. REv. 797, 800 (1957).

69 UAW v. Hoosier Cardinal Corp., 383 U.S. 696, 701 (1966).

${ }^{70}$ See Lincoln Mills, 353 U.S. at 457 ("The range of judicial inventiveness will be determined by the nature of the problem."); see also Illinois v. City of Milwaukee, 406 U.S. 91, $105 \&$ n.6 (1972) (noting that interstate disputes, by their nature, require uniform federal rules of decision).

${ }^{71}$ See Wilson, 471 U.S. at 266 (noting that the Court's "settled practice" has been to borrow a provision of local law); id. at 280 (O'Connor, J., dissenting) (observing that the practice of adopting analogous state law traces its lineage to cases decided in the 1800's); see also Agency Holding Corp. v. Malley-Duff \& Assocs., Inc., 107 S. Ct. 2759,2768 (1987) (Scalia, J., concurring) (observing that "the virtually uniform practice [is] to look to applicable state statutes").

${ }_{72}$ See Kimbell Foods, 440 U.S. at 729 (stating that the Court "must consider the extent to which application of a federal rule would disrupt . . . relationships predicated on state law."); Bank of America Nat'l Trust \& Sav. Ass'n v. Parnell, 352 U,S. 29, 33-34 (1956) (holding that when the litigation concerns a dispute between private parties, the United States' interest in the subject matter of the dispute is insufficient to 


\section{What Does the Court Have the Power to Do?}

The Court's carefully limited statement of its task, and its painstaking specification of both the rationale for its power and its discretionary choices in filling a statutory gap, seem an elaborate ritual for the modest task of selecting a time limitation-a task the Court portrays as a matter of "borrowing" a timeliness rule that some other authority has created. When Congress passes a statute creating a private cause of action but does not specify a time bar, the Court "do[es] not ordinarily assume that Congress intended that there be no time limit on actions at all; rather, [its] task is to 'borrow' the most suitable statute or other rule of timeliness from some other source."73 Possible sources include states' general statutes of limitations, time bars from analogous federal statutes, and common law time limitations. Most frequently, the Court has borrowed from the states.

As a result of this practice, time limitations on suits brought to vindicate federally-created rights are curious phenomena. On the one hand, various traditions and precedents suggest that such limitation is a matter of state law functioning of its own force to place restrictions on the way federal policy is implemented. ${ }^{74}$ On the other hand, rules that vitiate a person's opportunity to gain access to the courts in connection with a particular right are integral to the policy being implemented, ${ }^{75}$ and after being adopted as federal common law implementing the statute, apply to the states via the supremacy clause. ${ }^{76}$

\section{Essential Characteristics of Statutes of Limitation}

All fifty states and the District of Columbia have general statutes of limitations. ${ }^{77}$ Some substantive statutes (whether state or federal)

preempt state governing law).

${ }_{73}$ DelCostello v. International Bhd. of Teamsters, 462 U.S. 151, 158 (1983).

74 See Malley-Duff, 107 S. Ct. at 2768-71 (Scalia, J., concurring) (using a theory of law to explain the history of applying state statutes of limitations to federal causes of action); Campbell v. Haverhill, 155 U.S. 610, 620 (1895) (holding that even rights created by Congress may be subject to state statutes of limitations). See generally Mishkin, supra note 68, at 805 (discussing circumstances in which "local law applies of its own authority").

${ }_{75}$ See Occidental Life Ins. Co. v. EEOC, 432 U.S. 355, 361 (1977); Holmberg v. Armbrecht, 327 U.S. 392, 396 (1946).

${ }^{76}$ Ordinarily, neither federalism nor supremacy clause issues are raised because the state and federal judiciary's interests in statutes of limitation are fully compatible. Their common interests concern providing a fair forum to adjudicate rights under law (whether state or federal). See Special Project, Time Bars in Specialized Federal Common Law: Federal Rights of Action and State Statutes of Limitations, 65 CoRNELL L. REv. 1011, 1045-55 (1980) [hereinafter Time Bars].

${ }_{77}$ See Developments in the Law-Statutes of Limitations, 63 HaRv. L. REv. 
specify their own periods of limitation. ${ }^{78}$ When a state statute specifies its own time bar, the state's general statute of limitations is preempted. And conversely, when the substantive statute is silent, the court selects the relevant limitation period from the general statute. There is no general federal statute of limitations for civil suits, ${ }^{79}$ although there is a five-year limitation on federal criminal prosecutions. ${ }^{80}$

Most of the general statutes of limitations adopted by the states were based on the pattern articulated in the time of James $I^{81}$ They provide a general scheme for categorizing different causes of action and a time limitation for claims that fall within each category. A familiar pattern uses categories from common law forms of pleading, such as contract, debt, personal injury, trespass, and replevin. ${ }^{82}$ Often the statute also provides a "catchall" general limitation period for those actions that do not fit into the specific categories. ${ }^{83}$ For each group, the statute

1177, 1179 (1950) [hereinafter Developments-Limitations].

${ }_{78}$ See id. at $1179-80$.

${ }^{79}$ There was legislation in the 79th Congress proposing a one-year general federal statute of limitation. It was opposed by the Attorney General as too short for trademark and copyright actions, actions under the Civil Rights Acts, and private antitrust suits. See id. at 1268 n.754.

${ }^{80}$ Statutory authority for the five-year criminal limitation is found in two separate code locations. Title 18 U.S.C. $\S 3282(1982)$ provides a five year limit on criminal prosecutions, trials, and punishments, for non-capital offenses. Title 28 U.S.C. $\S 2462$ (1982) provides: "Except as otherwise provided by Act of Congress, an action, suit or proceeding for the enforcement of any civil fine, penalty, or forfeiture, pecuniary or otherwise, shall not be entertained unless commenced within five years from the date when the claim first accrued." Although the wording seems to connote a general period of limitations, the courts have consistently interpreted the phrase "penalty or forfeiture" as pertaining to criminal prosecutions. See Time Bars, supra note 76, at 1014-23. But see Sierra Club v. Chevron U.S.A., 834 F.2d 1517, 1521 (9th Cir. 1987) (applying $\S 2462$ to citizen enforcement actions brought under the Clean Water Act).

${ }^{81}$ See Blume \& George, Limitations and the Federal Courts, 49 MicH. L. REv. 937, 964 (1951). The statute of James I, An Act for Limitation of Actions, and for Avoiding of Suits in Law, 1623, 21 Jac. ch. 16, was the first to limit actions to a period of years. Earlier limitations on various actions to recover property had specified an historical period during which one's ancestor had to have been seized of the property in question in order to bring an action at law. See W. Ferguson, The Statute of Limitations Savings Statutes 7-8 (1978); see also J. ANGeli, A Treatise on THE Limitations OF ACTIONS AT LAW 10 (6th ed. 1876) (noting that the limitations statute of James I was generally adopted by the American states).

82 See Developments-Limitations, supra note 77, at 1179. For example, the general statute of limitations enacted for the Commonwealth of Pennsylvania in 1713, Act of March 27, 1713, ch. 196, 1700-1781 Pa. Laws (1 Smith) 76, remained valid law until it was repealed in 1978 by Act No. 53, $1978 \mathrm{~Pa}$. Laws $202, \S 2$. The new general statutes of limitations, 42 PA. Cons. Stat. ANN. $\S \$ 5523-27$ (Purdon Supp. 1987) essentially preserve the system of characterizing claims in terms of their analogous common law forms of action.

${ }^{83}$ For example, Pennsylvania's catchall provides: "Any civil action or proceeding which is neither subject to another limitation specified in this subchapter nor excluded from the application of a period of limitation by section 5531 (relating to no limitation) must be commenced within six years." 42 PA. Cons. STAT. ANN. $§ 5527$ (Purdon 
specifies a fixed period of time after the accrual of the cause of action during which a plaintiff must commence her suit. ${ }^{84}$ However, the states differ in their choice of categories, and in the duration of the statutory period for any particular class of action. ${ }^{85}$ In order to determine whether an action filed in a particular state is time-barred, one must first characterize the plaintiff's claim in terms of one of the categories employed in that state's statute, ${ }^{86}$ and then ascertain whether the action has been filed within the relevant period. ${ }^{87}$

\section{Underlying Policy Interests}

In Bell v. Morrison, ${ }^{88}$ Justice Story wrote of statutes of limitation: "It is a wise and beneficial law . . . to afford security against stale demands, after the true state of the transaction may have been forgotten, or be incapable of explanation, by reason of the death or removal of witnesses." ${ }^{189}$ The benefits of such laws accrue to the administration of justice-a matter considered weighty enough to warrant limiting the availability of a forum for vindicating federally-created rights. Thus, the policy justification for limiting substantive rights is not found in the

Supp. 1987).

84 See Developments-Limitations, supra note 77, at 1179 ("While the language varies among the states, most statutes provide either that 'all actions . . . shall be brought within' or 'no action . . . shall be brought more than' so many years after 'the cause thereof accrued.' ") (ellipses in original).

${ }^{85}$ See Blume \& George, supra note 81, at 965; Note, Federal Statutes Without Limitations Provisions, 53 Colum. L. Rev. 68, 69 (1953).

88 "Characterizing the claim" can be a controversial matter. In characterizing a claim brought under 28 U.S.C. § 1981, for example, Justice Brennan dissented from the portion of the majority opinion that held that such actions were governed by the State's two-year limitation on personal injury actions. Goodman v. Lukens Steel Co., 107 S. Ct. 2617, 2625 (1987) (Brennan, J., concurring in part and dissenting in part). Based on the legislative history of this section Justice Brennan reasoned that the purpose of the provision was to prevent racial discrimination that might impair the economic rights of blacks to form contracts and generally participate in commerce. Accordingly, he maintained that actions brought under $\S 1981$ were governed by the State's six year limitation on contract actions. See id. at 2631.

${ }_{87}$ Whatever the duration of a state's limitation period, it runs from the accrual of the action to commencement of the lawsuit. Although the states differ in regard to the appropriate definitions of "accrual" and "commencement," federal law, not state law, governs the accrual of a federal cause of action. See Cope v. Anderson, 331 U.S. 461, 464 (1947). Moreover, the Supreme Court has recently held that where the underlying cause of action is based on federal law, filing a complaint in accord with Federal Rule of Civil Procedure 3 within the appropriate statutory period constitutes timely commencement of the action. See West v. Conrail, 107 S. Ct. 1538, 1541 (1987). Nevertheless, "commencement" for the purposes of actions whose federal jurisdiction is based on diversity of citizenship is defined by state law. See Walker v. Armco Steel Corp., 446 U.S. 740, 752-53 (1980).

8s 26 U.S. (1 Pet.) 351 (1828).

${ }^{89}$ Id. at 360 . 
right itself, but in other societal interests.

The virtues of time bars are conventionally discussed in terms of the institutional and societal interests served by statutes of repose. ${ }^{90}$ The institutional interests include such concerns as judicial efficiency and economy-court time should not be consumed in litigating stale claims. Such a limitation is supported by the theory that minimizing the number of decisions that must be based on inadequate evidence and testimony that has been clouded by fading memories will enhance the perceived fairness of the judicial system. ${ }^{91}$ But regardless of whether they enhance the public's perception of the judicial system, statutes of limitation are by now rather uniformly recognized as a useful mechanism for reducing court dockets. ${ }^{92}$

Societal interests in statutes of limitation pertain to protecting the parties' repose. ${ }^{93}$ The underlying social policies are that it is undesirable to make people perpetually liable for their transgressions and that a limitation period should not be too brief to allow a plaintiff to prepare her case. Apart from these general guidelines indicating that limitation periods should be neither too long nor too short, there are relatively few indications of why a given period of limitation may be more suitable than another. ${ }^{94}$

\section{Right and Remedy/Substance and Procedure}

At common law, the running of the statute of limitation was an

so Cf. Time Bars, supra note 76, at 1016-18 (discussing the "institutional," "remedial," and "promotional" purposes of time bars).

${ }^{91}$ See Burbank, Of Rules and Discretion: The Supreme Court, Federal Rules and Common Law, Notre Dame Law School: Symposium on the Fiftieth Anniversary of the Federal Rules of Civil Procedure, February 26, 1988 at 4 (arguing that once one lifts the trappings of rationality that attend "characterizing the claim" for borrowing purposes, and the process is shown to be somewhat arbitrary, there may be a significant loss of respect for the courts); Developments-Limitations, supra note 77, at 1260 ("[G]eneral statutes of limitation . . . reflect the forum's determination of the time after which its courts can no longer operate fairly and effectively." (citations omitted)).

92 See, e.g., United States v. Western Pac. R.R., 352 U.S. 59, 72 (1956) (the "purpose of [statutes of limitation] is to keep stale litigation out of the courts"). See also Burbank, supra note 91, at 5 .

${ }_{93}$ See Allen v. United States, 542 F.2d 176, 179 (3d Cir. 1976) (statutes of limitation "serve to strike a balance between the need for certainty and predictability in legal relationships and the role of the courts in resolving private disputes"), cert. denied, 434 U.S. 985 (1977); see also W. Ferguson, supra note 81, at 46 (observing that courts often refer to statutes of limitation as "statutes of repose"); Developments-Limitations, supra note 77, at 1185 ("the public policy of limitations lies in avoiding the disrupting effect that unsettled claims have on commercial intercourse.").

94 Some commentators have taken the view that the precise duration is completely arbitrary. See Note, supra note 85 , at 75 . 
absolute bar to a plaintiff's legal remedy. ${ }^{95}$ Interpretations of the general statutes of limitations construed the statutory language (e.g., "no action shall be brought") to mean that the limitation applied to the remedy but not to the underlying right. ${ }^{96}$ The distinction between right 'and remedy is based on the hypothetical bifurcation of a plaintiff's cause of action into two parts: a right, created by the lex loci, and a remedy, created by the lex fori. The lex fori, or law of the forum state, includes rules of court procedure and general statutes of limitations which "reflect the forum's determination of the time after which its courts can no longer operate fairly and effectively." $\mathrm{Or}$, as the plaintiff argued in the Supreme Court's first case regarding the appropriate limitation for a federal right:

Statutes of limitation are leges fori; and it rests with the sovereign power of the state to say how far the interests of the society it represents require that its own Courts shall be kept open to give redress in each particular case, or whether there shall be any limitation of personal actions. ${ }^{98}$

Therefore, the fact that general statutes of limitation were considered part of the procedural and evidentiary rules of the forum state may be significant in evaluating contemporary interpretations of the early cases.

Early courts used the distinction between right and remedy to ameliorate the harsh effects of time limitations. For example, the distinction made it possible to say that while the remedy had been extinguished by the statute, the underlying right sued upon was still intact. ${ }^{99}$ The survival of the right beyond the remedy allowed litigation of collateral and equitable remedies despite the running of the statutory period. ${ }^{100}$

95 For this reason, common law courts were often hostile to statutes of limitations. See, e.g., Tynan v. Walker, 35 Cal. 634, 643 (1868) (referring to the "well known hostility" of courts to statutes of limitations); Ford v. Schall, 110 Or. 21, 27-28, 221 P. 1052, 1054 (1924) (same).

${ }^{86}$ See Developments-Limitations, supra note 77 , at 1186-88.

${ }^{97}$ Id. at 1260 (citing M'Elmoyle v. Cohen, 38 U.S. (13 Pet.) 312, 327 (1839)).

${ }^{88}$ M'Cluny v. Silliman, 28 U.S. (3 Pet.) 270, 272 (1830). The court affirmed this assertion, stating that "[i]t is a well settled principle, that a statute of limitations is the law of the forum, and operates upon all who submit themselves to its jurisdiction." Id. at 276-77 (emphasis added).

${ }^{90}$ See Developments-Limitations, supra note 77 , at 1187 . The convenient fiction that rights have perpetual lives, while remedies have a limited duration, allowed courts to "waive" the bar, or "revive" the remedy in the interest of justice, without creating a new right upon which to base the plaintiff's recovery once the statutory period had lapsed.

100 See id. 
An entirely different situation obtained when the limitation period was provided in the statute granting the right. These so-called "substantive time limits" were regarded as a "condition" of the right, and the running of the statute measured the life of the right itself. ${ }^{101}$ The courts' differential treatment of substantive time limits not only barred assertion of collateral remedies after the statutory period, it also eliminated the various savings provisions that had been created to provide remedies after the statutory period had run. ${ }^{102}$ For example, some courts held that rights with substantive time limits were exempt from the equitable tolling provisions that protected plaintiffs' rights in the event of disability or unavoidable delay in litigating their claims. ${ }^{103} \mathrm{In}$ deed, as recently as 1949 , this prohibition was routinely applied to federal civil actions with substantive time bars. ${ }^{104}$ As one commentator observed in discussing the "rigidity of the conventional view": "[U]nlike a general statute of limitations, the statutory time limit cannot be waived or tolled and the cause of action expires at the termination of the statutory period."105 This strict approach to substantive time bars, in comparison to the judiciary's willingness to construe interpretively the running of the general statutes of limitation, indicates that by specifying a limitations period when creating a new right, legislatures were effectively preempting judicial discretion-implicitly requiring the courts to exercise a more mechanical, rigid approach to the expiration of plaintiffs' cause of action. This is arguably a powerful incentive for those legislators who support the creation of a right to resist enacting a specific limitations period.

101 See id. at 1188. Compare Davis v. Mills, 194 U.S. 451, 454 (1904) (Holmes, J., for the Court) ("[O]rdinary limitations of actions are treated as laws of procedure and as belonging to the lex fori, as affecting the remedy only and not the right.") with The Harrisburg, 119 U.S. 199, 214 (1886) ("The time within which the suit must be brought operates as a limitation of the liability itself as created, and not of the remedy alone. It is a condition attached to the right to sue at all.").

102 See Developments-Limitations, supra note 77, at 1188.

${ }_{103}$ See, e.g., Smith v. Eureka Pipe Line Co., 122 W. Va. 277, 281, 8 S.E.2d 890, 892 (1940) (The statute of limitations "could not have been intended to include proceedings for death by wrongful act . . . ."); see also Recent Case, 63 HARV. L. REv. 711,711 (1950) ("Traditionally, a limitation in a statute creating a cause of action which did not exist at common law has been treated not as a limit on the remedy but as a condition of the right itself."). 1949).

${ }^{104}$ See Frabutt v. New York, C. \& St. L.R.R., 84 F. Supp. 460, 464 (W.D. Pa.

${ }_{105}$ Recent Case, supra note 103, at 712. A string of cases arising out of World War II marked a change in the courts' view of tolling provisions for federal causes of action. See, e.g., Osbourne v. United States, 164 F.2d 767, 769 (2d Cir. 1947) (Jones Act limitation suspended by war); Frabutt, 84 F. Supp. at 464 (FELA time limitation suspended by war); Grossman v. Young, 72 F. Supp. 375, 379 (S.D.N.Y. 1947) (Securities Exchange Act limitation tolled by fraud). 
Today, the accepted view is that all statutes of limitation are substantive rather than procedural. ${ }^{106}$ But as of 1950 , a commentator could still write: "[T]he general statutes of limitations are ordinarily considered to be procedural rather than substantive . . .."10z Although the distinction between substance and procedure is an elusive one, it became crucial after the Rules Enabling Act of 1934: the Federal Rules of Givil Procedure can neither "abridge, enlarge, nor modify the substantive rights of any litigant."108

The need to reconceive statutes of limitation as substantive law arose from the fact that the Federal Rules obviated the need for the right/remedy distinction in most other areas of pleading and practice. A necessary part of the project was reuniting the limitation on the action with the substantive action itself. ${ }^{109}$ But the Advisory Committee was authorized to develop rules of procedure, not to reformulate state statutes of limitations or amend federal substantive law. Moreover, the seemingly simple option of declaring statutes of limitation "procedural" and providing a general federal limitations scheme was not realistically available to the Advisory Committee. ${ }^{110}$

First, some federal statutes include their own time bars. Allowing these statutes to, in effect, preempt one of the uniform procedural requirements would have detracted from the uniformity and integrity promised by the new rules. ${ }^{111}$ If an organic statute can preempt a pro-

108 Traditional conflict of laws analysis regards statutes of limitation as procedural (i.e., lex fori). See R. Weintraub, Commentary on the Conflict of Laws $\S 3.2 \mathrm{C} 2$ n.46 (3d ed. 1986). However, a judge-made exception to the procedural classification evolved for those time bars that were considered "substantive" in the relevant jurisdiction. See, e.g., Johansen v. E.I. DuPont de Nemours \& Co., 810 F.2d 1377, 1381 (5th Cir.) ("I] [ [the] jurisdiction's limitations period is considered substantive, that provision will govern."), cert. denied, 108 S. Ct. 148 (1987).

${ }_{107}$ Developments-Limitations, supra note 77, at 1180 .

108 Rules Enabling Act, Pub. L. 73-415. 48 Stat. 1064, § 1 (current version at 28 U.S.C. $\S 2072(1982))$.

${ }_{100}$ See Burbank, The Rules Enabling Act of 1934, 130 U. PA. L. REv. 1015, 1021 (1982) (noting the Senate's awareness that limitations were not simply a procedural matter); id. at 1159 n.620 (reporting the Advisory Committee's debate regarding the relation between Rule 3 and tolling provisions for statutes of limitation). As Justice Frankfurter said:

[T] ]he question is not whether a statute of limitations is deemed a matter of "procedure" in some sense. The question is whether such a statute concerns merely the manner and the means by which a right to recover, as recognized by the State, is enforced, or whether such statutory limitation is a matter of substance in the aspect that alone is relevant to our problem ....

Guaranty Trust Co. v. York, 326 U.S. 99, 109 (1945).

110 See Blume \& George, supra note 81 , at 937.

11 See Burbank, supra note 90, at 24-32 (arguing that the elusiveness of the simplicity and uniformity promised by transsubstantive procedure calls for a careful 
cedural time bar, why should legislators abstain from attaching exemptions from other procedural requirements to statutes pertaining to their favored cause of action?

Second, because much of the jurisdiction of the federal courts is concurrent with that of the states, an expressly procedural general federal statute of limitations would have meant that a different time bar applied to the same cause of action depending upon whether the plaintiff chose to sue in state or federal court. ${ }^{112}$ Accordingly, statutes of limitation were left to be promulgated by Congress and state legislatures as a matter of substantive law.

\section{The Boundaries of the Court's Power}

It was generally understood at common law that in addition to interpretively applying the general statutes of limitation, that judges had the power to impose their own time bars. ${ }^{113}$ Examples of judgemade time bars include rules that have become familiar hornbook maxims: the presumption of satisfaction for notes that are uncollected for twenty years, the presumption of death for persons absent for seven years, the year and a day murder rule, and the rule against perpetuities. $^{114}$ These judge-made time bars and the equity courts' use of the doctrine of laches ${ }^{115}$ demonstrate that the authority for these time bars derives from the courts' authority to make common law, rather than the authority of the legislature as reflected in the general statutes of limitations. ${ }^{116}$ Accordingly, when federal courts borrow from a general statute of limitations to impose a time limitation on a federal cause of action, they are not only acting upon their power to make federal common law; they are well within the parameters of the general authority of common law courts.

reexamination of the relation between substantive and procedural law).

112 The Advisory Committee is likely to have been well aware that this "vertical" nonuniformity of the law that applied in state and federal courts of the same state, was thought to promote forum shopping by prospective plaintiffs. Indeed, Erie, which was designed to remedy vertical nonuniformity in substantive law, was decided in the same year in which the Federal Rules were promulgated.

113 See UAW v. Hoosier Cardinal Corp., 383 U.S. 696, 713 (1966) (White, J., dissenting) ("Courts have not always been reluctant to 'create' statutes of limitations ....").

114 See Time Bars, supra note 76, at 1015 n.12.

116 Laches, a doctrine that can be invoked by a defendant in equity, depends on the maxim that "equity aids only the vigilant." See Note, Laches in Federal Substantive Law: Relation to Statutes of Limitations, 56 B.U.L. REv. 970, 971 (1976).

${ }_{116}$ See Hoosier Cardinal, 383 U.S. at 713 (White, J., dissenting); Time Bars, supra note 76, at 1015 n.12. 


\section{Meta-legal Considerations in \\ the Exercise of the Court's Power}

In exercising their power to make federal common law judges provide us with a unique opportunity to observe the effects of their metalegal orientations. The label "meta-legal framework" refers to the nonconscious assumptions and beliefs about law, legal institutions, and her own task as a member of the legal profession, that inform an individual's perceptions and analyses of legal problems. ${ }^{117}$ These assumptions are integral to an individual's initial perception of a legal problem, and provide the "raw material" to which she more purposefully applies the formally-acquired tools of legal analysis. ${ }^{118}$ The present discussion will focus on three aspects of a meta-legal framework that pertain to the function of the courts in the structure of our government. They concern the courts' role in dispute resolution, in law declaration, and as an institutional guardian. All three functions are integral to the role of courts in the American system, but different judges may emphasize one or another element. This differential emphasis affects what facts the judge finds significant, what legal theories are most persuasive, and what overarching considerations are taken into account in formulating federal common law.

\section{Dispute Resolution}

The dispute resolving function derives from the article III requirement that courts adjudicate cases and controversies brought by private parties. Differing meta-legal orientations toward this function range from acknowledging that private parties' disputes govern the agenda of issues the court may consider, ${ }^{119}$ to an affirmative mandate that judges restrict their attention to the facts of a specific dispute in reaching their decision.

The latter approach was characteristic of the Legal Realists. ${ }^{\mathbf{1 2 0}}$

117 See supra note 17.

118 See M. Merleau-Ponty, Phenomenology of Perception 207-42 (C. Smith trans. 1962); id. at 242 ("[R]eflection does not itself grasp its full significance unless it refers to the unreflective fund of experience which it presupposes, upon which it draws, and which constituted for it a kind of original past, a past which has never been a present."); Pribram, Some Comments on the Nature of the Perceived Universe, in Perceiving, Acting, and Knowing: Toward an Ecological Psychology 83-101 (R. Shaw \& J. Bransford eds. 1977) (discussing the relation between conceptual, neural, and physical structures).

110 See, e.g., Fiss, supra note 17, at 13 ("Judges are not in control of their agenda, but are compelled to confront grievances or claims they would otherwise prefer to ignore.").

120 See generally K. Llewellyn, The Bramble Bush: On OuR Law and Its 
Because the Realist lawyers focused on the facts and setting of particular disputes, "law was to be found in the sensitive formation of highly particularistic rules, and in the Realistic refusal to generalize those rules beyond the particular contexts that gave them meaning." "121 Hence, the "law" created by a Realist judge is based on a narrowly drawn situation that does not readily lend itself to generalizations regarding new disputes that deviate from the standard fact pattern. This approach fosters situation-specific legal concepts such as "reliance," "unconscionability," and "unequal bargaining power."

The Realists' focus on the facts of a particular dispute contrasts markedly with Professor Fiss's view that disputes are essentially the means by which a judicial agenda is established. ${ }^{122}$ Fiss affirms that

[d]isputation can . . . be viewed as a mode of judicial operation. I will also concede that the judge's decision may bring an end to the dispute; dispute resolution may be one consequence of the judicial decision. But . . . it is equally important to recognize that the function of the judge-a statement of social purpose and a definition of role-is not to resolve disputes, but to give the proper meaning to our public values. ${ }^{123}$

Professor Fiss goes on to argue that resolving disputes which implicate no question of public values is more properly a matter for arbitration (paid for by the disputants), rather than a matter for adjudication (paid for by public funds). ${ }^{124}$

In articulating public values the judge is not simply applying her own values and preferences to resolve the dispute; she is required to distance herself from the dispute and her personal values. The judge

is ... required to be independent. This means, for one thing, that he not identify with or in any way be connected to the particular contestants. He must be impartial, distant, and detached from the contestants, thereby increasing the likelihood that his decision will not be an expression of the self-interest (or preferences) of the contestants, which is the

STUdy (1960) (describing law from a Realist perspective); W. Rumble, AMERICAN Legal Realism: Skepticism, Reform, and the Judicial Process (1968) (analyzing the Legal Realist movement); Pound, The Call for a Realist Jurisprudence, 44 HARv. L. REv. 697 (1931) (criticizing the Legal Realist movement).

121 B. ACKerman, Reconstructing AMERICAN LAw 18-19 (1984).

122 See Fiss, supra note 17, at 13,29 ("[C]ourts exist to give meaning to our public values, not to resolve disputes.").

${ }^{123} \mathrm{Id}$. at 30.

124 See id. at $30-31$. 
antithesis of the right or just decision. The norm of impartiality also requires that the judge . . . . must not view his job as one of registering [the] preferences [of the populace]. ${ }^{125}$

As a result of this detached independence, Fiss's approach leads judges to postulate fundamental values that transcend situations and inform just decisions in particular cases. In contrast to the situation-specific legal concepts of the Realists, these transcendent legal values-identified anew in individual cases-provide guidelines for resolving disputes in context.

\section{Law Declaration}

The law declaring aspect of a judge's meta-legal orientation concerns the theory or concept underlying her understanding of what "law" is. When a court makes common law, both the form and substance of the particular rule it creates reflect this theory. Perhaps the most widely-recognized theory of law is the familiar conception of a transcendent web of common law that the judge "discovers" through the process of adjudication. ${ }^{126}$ The Restatement movement of the 1920's represented an attempt to make explicit the overarching principles implicit in the warp and woof of this all-encompassing common law. ${ }^{12 t}$

Professor Fiss's concept of fundamental constitutional values ${ }^{128}$ also defines a view of law, as does the general philosophy of the law and economics movement. In addition to its obvious use of principles from economics (e.g., "efficiency," "market forces," etc.) as bases for legal decisions, ${ }^{129}$ the "law and economics" rhetoric has been used to describe a more global approach to law, in which lawyers attend to the ex ante effects of legal decisions on behavior. ${ }^{130}$ Whether or not one employs traditional economic terms to formulate such questions, conceiving of lawmaking as an activity involving anticipation of the impact of legal rules on the subsequent behavior of non-parties is, for our purposes, a view that affects legal decisionmaking.

125 Id. at 14.

${ }^{128}$ See supra notes 25-26 and accompanying text.

127 See G. WhITE, TORT LAW IN AMERICA 8-12 (1980); Goodrich, The Story of the American Law Institute, 1951 WASH. U.L.Q. 283, 286-92.

${ }^{128}$ See supra notes $122-25$ and accompanying text.

129 See generally R. Posner, Economic AnAlysis of LAw (3d ed. 1986) (outlining a method for translating legal analysis into economic terms).

${ }_{130}$ See, e.g., B. ACKerman, supra note 121, at 48-65 (exploring the value of ex ante rather than ex post legal reasoning). 


\section{Institutional Guardianship}

The Supreme Court's role as an institutional guardian derives from its unique position in our system of government as a guardian against tyranny. The risk of tyranny envisioned by the Framers of the Constitution was thought to be inherent in a concentration of power in any one office or institution. ${ }^{131}$ The unique position of the judiciary derives from the life tenure and protected salary provisions for federal judges (which are designed to shield them from direct political influence) and their lack of control over their agendas. ${ }^{132}$ That is, the Court is not free to pursue issues of perceived importance in the same manner as the legislature or the executive; it must wait until such issues are presented in cases and controversies brought by private parties, or prosecuted by the executive branch of the government. ${ }^{133}$ The Court's role as an institutional guardian may be expressed as a deferential orientation toward preserving the integrity of actions taken by the other branches, ${ }^{134}$ or as a more aggressive insistence that other branches perform their function as the Court interprets it. ${ }^{135}$

The former, deferential approach is evident in the post-Lochner ${ }^{136}$ concern with minimizing the Court's interference with legislative intent, ${ }^{137}$ as well as the general orientation toward discriminatory social

131 See, e.g., The Federalist No. 51, at 358 (J. Madison) (H. Jones ed. 1961) ("Whilst all authority... will be derived from and dependent on the society, the society itself will be broken into so many parts . . . that the rights of individuals, or of the minority, will be in little danger from interested combinations of the majority.").

132 Among the lessons learned from the "public choice" movement is the salience of agenda manipulation as a device for controlling the outcome of a decision process. See W. Riker \& P. Ordeshook, An Introduction to Positive Political TheoRy 97-100 (1973); H. Rosen, Public Finance 113-14 (1985); Levine \& Plott, Agenda Influence and Its Implications, 63 VA. L. REv. 561, 570 (1977).

133 The importance of an external, citizen and/or executive-based control over the judiciary's agenda underlies the criticisms of the Court's use of jurisdiction, standing, mootness, and ripeness doctrines to avoid particular cases, and the increasing use of certiorari to "select" the Supreme Court's case load. See Gunther, The Subtle Vices of the "Passive Virtues"-A Comment on Principle and Expediency in Judicial Review, 64 Colum. L. Rev. 1, 10-13 (1964).

134 See, e.g., Railroad Retirement Bd. v. Fritz, 449 U.S. 166, 179 (1980) ("Where, as here, there are plausible reasons for Congress' action, our inquiry is at an end."); Williamson v. Lee Optical Inc., 348 U.S. 483, 487 (1955) ("II]t is for the legislature, not the courts, to balance the advantages and disadvantages of the new requirement."); Railway Express Agency v. New York, 336 U.S. 106, 109 (1949) (hypothesizing a rational basis for the legislative action).

${ }^{138}$ See, e.g., G. Calabresi, A Common Law for the Age of Statutes $146-$ 62 (1982) (advocating numerous aggressive techniques the judiciary can employ to invalidate obsolete statutes and/or require the legislature to reform such statutes).

${ }^{136}$ Lochner v. New York, 198 U.S. 45 (1905).

${ }^{137}$ See West Coast Hotel Co. v. Parrish, 300 U.S. 379, 398-99 (1937) ("legislature was entitled to adopt" laws consistent with their deep-seated convictions); Nebbia v. New York, 291 U.S. 502, 539 (1934) (a regulation "is unconstitutional only if arbi- 
programs embodied in one aspect of footnote four of the Carolene Products decision. ${ }^{138}$ Regardless of the level of scrutiny applied to legislative decisions, the assumption warranting judicial intervention in this approach is that there has been a failure at some stage of the legislative process. That is, the majoritarian processes of government have failed to adequately protect the interests of a minority. This failure of the political process is used to justify judicial intrusion into the putatively legislative sphere of social policy. Absent such a failure, judicial invalidation of a duly enacted legislative program is unwarranted.

An approach predicated on legislative failure is necessarily affected by the judiciary's foundation definition of "legislative failure." That is, failure may involve abrogating the rights of individuals (as in the Carolene Products analysis); it may encompass a perceived neglect of federalism concerns, (as the Court maintained in National League of Cities v. Usery ${ }^{\mathbf{1 3 9}}$ ); or, it may involve allegedly inadequate detail in delegating important legislative responsibility to an executive agency. ${ }^{\mathbf{1 4 0}}$ Accordingly, while the rhetoric of institutional guardianship connotes deference to the legislative function, ${ }^{141}$ such an approach lends itself to an active scrutiny of legislative enactments according to whatever model of our system of government is embodied in the Court's definition of legislative "failure." Thus, for example, Calabresi has advocated that the Court explicitly overturn obsolete statutes, and interpret others in such a way that the legislature must readdress the subject matter if there is to be a policy other than that embodied in the Court's new common law. ${ }^{142}$

By selectively using such an adversarial strategy, the Court can control the legislative agenda on important social issues. As Professor Weisberg notes, rather than allowing the legislature to rely on customarily modest judicial interpretations of previously enacted statutes, an aggressive judicial strategy shifts the burden to the legislature to veto

trary, discriminatory, or demonstrably irrelevant to the policy the legislature is free to adopt").

${ }^{138}$ United States v. Carolene Prods. Co., 304 U.S. 144, 152 n.4 (1938).

139426 U.S. 833 (1976). See Comment, The Tenth Amendment After Garcia: Process-Based Procedural Protections, 135 U. PA. L. REv. 1657, 1681-86 (1987) (discussing a way of requiring Congress to consider the impact of legislation on federalism concerns).

140 See, e.g., Industrial Union Dep't. v. American Petroleum Inst., 448 U.S. 607, 672 (1980) (Rehnquist, J., concurring in the judgment) ("[T]his litigation presents the Court with what has to be one of the most difficult issues that could confront a decisionmaker . . . . Congress [is] best suited and most obligated to make the choice confronting us in this litigation ....").

141 See supra note 134.

142 See G. Calabresi, supra note 135 , at 163-66. 
the Court's "proposal,"143 for the common law process underlying judicial action means that a decision "interpreting" a statute or filling a gap will become the governing law. In effect, a justice's meta-legal orientation toward the Court's role as institutional guardian admits a confrontational role toward the legislature or the executive. ${ }^{144}$ Federal common law made in service of such a meta-legal consideration need not be grounded in a theory of law, an understanding of the dispute, or an interpretation of the statutory scheme whose interstices are being filled. Rather, it may serve the political purpose of furthering the particular conception of our system of government embodied in the definition of legislative (or executive) failure.

\section{Time Limitations on Federal Causes of Action}

The most recent case in which the Court addressed the question of an appropriate statute of limitations for a federal statutory cause of action was Agency Holding Corp. v. Malley-Duff $\mathcal{E}$ Associates, Inc. ${ }^{145}$ The federal cause of action in this case was brought under the private treble damages provision of the Racketeer Influenced and Corrupt Organizations Act (RICO). ${ }^{146}$ As enacted by Congress the statute does not provide a time limitation for the private damages remedy. Accordingly, as Justice Stevens had observed in an earlier case: "When Congress has not established a time limitation for a federal cause of action, the settled practice has been to adopt a local time limitation as federal law if it is not inconsistent with federal law or policy to do so."147 However, in Malley-Duff the Court held that "the practicalities of RICO litigation present ... compelling reasons for federal preemption of otherwise available state statutes of limitation." 148 The court concluded that:

there is a need for a uniform statute of limitations for civil RICO, that the Clayton Act clearly provides a far closer analogy than any available state statute, and that the federal policies that lie behind RICO and the practicalities of RICO litigation make the selection of the 4-year statute of limitations for Clayton Act actions the most appropriate limita-

143 See Weisberg, The Calabresian Judicial Artist: Statutes and the New Legal Process, 35 Stan. L. Rev. 213, 227 n.53 (1983).

${ }^{144}$ See Wellington \& Albert, Statutory Interpretation and the Political Process: A Comment on Sinclair v. Atkinson, 72 YALE L.J. 1547, 1566 (1963) (statutory interpretation offers a way of inducing confrontation with the legislature).

140107 S. Ct. 2759 (1987).

14618 U.S.C. § 1964(c) (1982).

147 Wilson v. Garcia, 471 U.S. 261, 266-67 (1985).

148 Malley-Duff, 107 S. Ct. at 2765-66. 


\section{tions period for RICO actions. ${ }^{149}$}

In this Part we will consider the rationale for the Court's decision in relation to recent decisions regarding statutes of limitation for other federal causes of action. Our objective is to discern the underlying meta-legal considerations that influence the Court's approach to filling the limitations gap in a congressional statute. Because the opinions of the majority and concurrence in Malley-Duff are informed by the legislative history and policy considerations underlying RICO, we will begin with a brief summary of the limitations problem presented by the statute.

\section{A. The RICO Statute of Limitations Problem}

The RICO provisions originally considered by Congress included neither a limitations provision nor a private damages remedy. ${ }^{150}$ The initial drafts of the Senate bill that was eventually enacted outlined a primarily criminal statute; the only private remedy it afforded was an injunction that might be sought by the Attorney General. ${ }^{151}$ Criminal actions brought pursuant to RICO would be subject to the catchall federal five year statute of limitations for criminal prosecutions. ${ }^{\mathbf{1 5 2}}$

RICO was intended to provide a more effective way to keep organized crime from infiltrating legitimate business, ${ }^{163}$ and to attack the economic base through which organized crime conducts its operations, so as to have "a more lasting impact upon the elimination of organized crime."164 For the various commissions and committees that studied the problem in the years preceding the enactment of RICO, antitrust enforcement and discovery procedures provided an important analogy for devising the new law enforcement tool. ${ }^{185}$ The American Bar Associa-

149 Id. at 2767 (citation omitted).

iso See generally TASK Force on Crvil RICO, A.B.A. Section of Corp. Banking and Business Law, Report of the Ad Hoc Civil, RiCO Task Force, 70-126 (1985) [hereinafter ABA TASK FORCE REPORT] (discussing the legislative history of RICO).

181 See id. at 96-97.

162 "Except as otherwise expressly provided by law, no person shall be prosecuted, tried, or punished for any offense, not capital, unless the indictment is found or the information is instituted within five years next after such offense shall have been committed." 18 U.S.C. \& 3282 (1982); see also supra note 80.

163 See 113 Cong. REc. 17,998-99 (1967) (statement of Sen. Hruska).

164 Measures Relating to Organized Crime: Hearings on S. 30, S. 974, S. 975, S. 976, S. 1623, S. 1624, S. 1861, S. 2022, S. 2122, and S. 2292 Before the Subcomm. on Criminal Laws and Procedures of the Senate Comm. on the Judiciary, 91st Cong., 1st Sess. 112 (1969) (statement of Attorney General Mitchell).

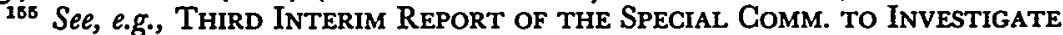
Organized Crime in Interstate Commerce, S. ReP. No. 307, 82nd Cong., 1st Sess. 170 (1951) ("A racketeer who has contempt for the law and who enters legitimate 
tion's Antitrust Section evaluated various bills that were before Congress in 1969, and endorsed the new approach: "[t]he time tested machinery of the antitrust laws contains several useful and workable features which are appropriate for use against organized crime."156 The Section specifically mentioned that civil enforcement by means of a private treble damages remedy, as well as criminal penalties, would be useful. ${ }^{167}$ When the House Judiciary Committee favorably reported the Senate bill in September 1970, it attached an amendment which added a private treble damages remedy. ${ }^{158}$ The amended bill passed the House by a vote of 341 to $26 .{ }^{169}$ It was received in the Senate on October $12,1970,{ }^{160}$ shortly before it was to adjourn for the November 1970 elections. The Senate adopted the House version without a conference to reconcile their differences. To have done otherwise with so little time remaining in the session would have required the reintroduction of another bill once the new Congress convened. ${ }^{161}$

Use of the private damages remedy grew slowly. Prior to 1980 , there were only nine reported decisions involving civil RICO, ${ }^{162}$ but the number has grown dramatically. The ABA RICO Task Force reported that in the best available database of approximately 270 published and unpublished federal civil RICO cases, five were decided in 1980, 19 in 1981,35 in 1982,89 in 1983, and 116 in $1984 .{ }^{163}$ The Task Force also collected questionnaire data concerning attorneys' RICO experience. ${ }^{164}$ Of the respondents with civil RICO experience, $74 \%$ favored amending the statute; ${ }^{165}$ one of the ten most frequently suggested amendments was the addition of an express statute of limitations. ${ }^{168}$

Prior to Malley-Duff, courts considering the statute of limitations issue had looked to state general statutes of limitations for guidance. ${ }^{\mathbf{1 6 7}}$ The ABA Task Force identified eighteen decisions in which the statute of limitations issue had been litigated. The duration of the period bor-

business has no hesitation in engaging in black-market practices. This gives him a considerable advantage over a more timid competitor and is one of the means whereby the racketeer can push such a competitor to the wall.").

${ }^{15 B}$ Report of ANTITRUST Section of the American Bar Association, reprinted in 115 Cong. REC. 6994, 6995 (1969).

167 See id. at 6995.

${ }^{158}$ See H.R. REP. No. 1549, 91st Cong., 2d Sess. 58 (1970).

159 See 116 Cong. Rec. 35,363 (1970).

${ }_{100}$ See id. at $36,280,36,294-96$.

161 See id. at 36,280-96, 37,264.

162 See ABA TASK FORCE REPORT, supra note 150, at 55.

${ }^{163}$ See id.

184 See id. at 58-59.

185 See id. at 62.

${ }^{168}$ See id. at 66.

${ }^{167}$ See id. at $387 \&$ n.632. 
rowed from the state statutes to decide these cases ranged from one year (from a usury statute) to six (from a fraud statute). ${ }^{168}$ The Task Force concluded:

[T] he law regarding the applicable statute of limitations for Givil RICO claims is confused, inconsistent, and unpredictable. The current approach is virtually guaranteed to incite complex and expensive litigation over what should be a straightforward matter. . . . The Task Force can see no way in which such disputation furthers RICO's objectives. . . .

Accordingly, the Task Force recommends that legislation be enacted amending RICO to provide an express statute of limitations. While the appropriate period is purely a policy determination, two possibilities immediately come to mind. The first would be the same four-year limitations period used by the antitrust laws that in so many respects served as a model for Civil RICO. The second would be the limitations period of five years (the general federal criminal statute of limitations) .... ${ }^{169}$

\section{B. The Malley-Duff Case on Appeal}

Malley-Duff \& Associates, Inc. was under contract to serve as the exclusive agent in Pittsburgh, Pennsylvania, for the Crown Life Insurance Company of Canada. Crown Life terminated the agency in 1978 after Malley-Duff failed to meet a production quota. The quota had been imposed nine months into the fiscal year, and Malley-Duff maintained that it was impossibly high, even for an annual quota. MalleyDuff charged that the quota was merely a device that Grown Life had been using to take over lucrative territories in more than six cities. ${ }^{170}$ The RICO claim further alleged that Crown Life, the Agency Holding Corporation, and other defendants constituted an enterprise that had fraudulently terminated the Malley-Duff agency, and had attempted to obstruct justice in a related suit. ${ }^{171}$ The district court granted summary judgment for defendants on the RICO claims stemming from the events pertaining to the alleged fraud, on grounds that they were barred by

168 See id. at 389 n.635.

${ }^{168}$ Id. at $391-93$.

170 See Malley-Duff \& Assocs., Inc. v. Crown Life Ins. Co., 792 F.2d 341, 343 (3d Cir. 1986).

171 See id. at 343-44 \& n.4. 


\section{the two year Pennsylvania statute of limitations. ${ }^{172}$}

One issue on appeal was whether the district court had applied the correct state statute of limitations. Both parties characterized the RICO allegations in terms of common law fraud; both parties also agreed that Pennsylvania's newly revised 1978 state statute of limitations applied. ${ }^{173}$ However, perfecting amendments in 1982 had added a new clause expressly including allegations of fraud within the two year limitations period, as opposed to the prior practice of allowing the catchall six year limitations period to apply. ${ }^{174}$ Malley-Duff had filed its complaint in 1981, and the relevant statute for this "intervening period" had been the subject of much litigation. ${ }^{175}$

This type of dispute is rather common in ascertaining which state limitations period might be appropriate for a federal statutory cause of action. ${ }^{178}$ Nevertheless, the Third Circuit declined to address this question. ${ }^{177}$ Instead, it followed a three-part inquiry based on the Supreme Court's decision in Wilson v. Garcia. ${ }^{178}$ As interpreted by the Third Circuit, the steps may be summarized as follows: 1) determine whether state or federal law controls the characterization of the claim; 2) decide whether all claims " should be characterized in the same way, or . . . evaluated differently depending upon the varying factual circumstances and legal theories presented in each individual case;" "and, 3) " "characterize the essence of the claim in the pending case, and decide which state statute provides the most appropriate limiting principle." "178

172 See id. at 344 (referring to 42 PA. Cons. Stat. ANN. $§ 5524$ (Purdon Supp. 1987)).

${ }_{173}$ See Malley-Duff v. Crown Life, 792 F.2d at 344-45 \& n.7.

174 Prior to 1982 , the Pennsylvania statute of limitations, 42 Pa. Cons. STAT. ANN. § 5524 (Purdon 1981), did not include an explicit provision for fraud. Some courts had applied $\S 5524(3)$, which pertains to "action[s] for taking, detaining or injuring personal property," while others had applied the residual catchall statute, $\S 5527$, which pertains to "[a]ny civil action . . . which is neither subject to another limitation . . . nor excluded from the application of a period of limitation." See A.J. Cunningham Packing Corp. v. Congress Fin. Corp., 792 F.2d 330, 332-34 (3d Cir. 1986); see also id. at 332 n.1 (listing district court cases following the two approaches). The 1982 amendments added $\S 5524(7)$ to the two year limitations statute, making it applicable to "any other action or proceeding sounding in trespass, including deceit or fraud." See id. at 334.

175 See Malley-Duff v. Crown Life, 792 F.2d at 344 n.7.

178 See Time Bars, supra note 76, at 1057-84.

177 It was later forced to do so in A.J. Cunningham, $792 \mathrm{~F} .2 \mathrm{~d}$ at 332 (holding that the six year limitation on fraud governed the intervening period).

178471 U.S. 261, 268 (1985).

${ }^{179}$ See Malley-Duff v. Crown Life, 792 F.2d at 345 (quoting Wilson, 471 U.S. at 268). Compare the steps articulated by the Third Circuit with Justice Stevens' quotation from Burnett v. Grattan, 468 U.S. 42, 47-48 (1984) (outlining the steps involved in interpreting the directions Congress provided in 42 U.S.C. $\S 1988$ for determining the relevant statutory period for civil rights claims), quoted in Wilson, 471 U.S. at 267. 
Based on this analysis, the court "conclude[d] that within each state all civil RICO claims should be characterized uniformly, in accordance with federal law, and that in Pennsylvania the most appropriate limitations period for all civil RICO claims is the six-year residual statute of limitations." 180 Because the Malley-Duff RICO claim was filed within six years of the allegedly fraudulent termination of its agency, the Third Circuit reversed the district court's dismissal of these claims. ${ }^{181}$ The Supreme Court granted certiorari ${ }^{182}$ "to resolve the important question of the appropriate statute of limitations for civil enforcement actions brought under RICO." "183

\section{G. The Supreme Court Majority Opinion}

The Supreme Court unanimously affirmed the judgment of the Third Circuit. But the two opinions produced by the Court applied two entirely different statutes of limitations from the one invoked by the Court of Appeals. Considered together with the limitations period applied by the district court, this case generated four different approaches to the appropriate statute of limitations for a single RICO claim-a record that provides a compelling illustration of the ABA Task Force's conclusion that judicial response to the statute of limitations question had been "confused, inconsistent, and unpredictable."184 The majority opinion, however, remedied this situation: it provided what is by all accounts a workable, practical statute of limitations. ${ }^{185}$ Writing for eight members of the Court, Justice O'Connor concluded that the Clayton $\mathrm{Act}^{\mathbf{1 8 6}}$ provided a better analogy than any available state statute, and selected it to provide a uniform statute of limitations for RICO actions. ${ }^{187}$ The process by which this decision was reached involved two

${ }^{180}$ Malley-Duff v. Crown Life, 792 F.2d at 345 (referring to 42 PA. Cons. Stat. ANN. $§ 5527$ (Purdon 1981)).

${ }_{181}$ See id. at 353. Judge Sloviter concurred in the court's judgment, but declined to borrow the state's catchall period. Instead, citing the argument she developed in her concurrence in A.J. Cunningham, $792 \mathrm{~F} .2 \mathrm{~d}$ at 337-41, she "would apply the four year statute set forth in . . . the Clayton Act." Id. at 356 (Sloviter, J., concurring).

182 See 107 S. Ct. 569 (1986).

${ }^{183}$ Malley-Duff, 107 S. Ct. at 2762.

184 ABA TASK FORCE REPORT, supra note 150, at 391.

188 The complexity of the question of an appropriate statute of limitations for civil RICO had become such an acute problem that both petitioners and respondents in this case argued for a uniform statute of limitations for civil RICO actions. See MalleyDuff, 107 S. Ct. at 2764 (citing Brief for Respondent at 17; Brief for Petitioner Crown Life at 12 ).

18815 U.S.C. §§ $12-27$ (1982 \& Supp. IV 1986).

${ }_{187}$ See Malley-Duff, 107 S. Ct. at 2767; Malley-Duff v. Crown Life, 792 F.2d at 356 (Sloviter, J., concurring in the judgment); infra text accompanying notes 200-01. 
broad inquiries: a "characterization" phase, and a "borrowing" phase. ${ }^{188}$

\section{Characterizing the Claim: The Power to Decide}

Like the Third Circuit, the Court cited Wilson as support for the proposition that "characteriz[ing] . . . a federal claim for purposes of selecting the appropriate statute of limitations is generally a question of federal law."'188 The Wilson Court also referred to Justice Stewart's opinion in UAW v. Hoosier Cardinal Corp. ${ }^{190}$ as support for its characterization analysis: "We agree that the characterization of this action for the purpose of selecting the appropriate state limitations provision is ultimately a question of federal law."191 Justice Stewart's opinion, however, is often read as being limited to characterizing claims arising under section 301 of the Labor Management Relations Act. ${ }^{192}$ Even in this limited area, he stated that "there is no reason to reject" characterizations based upon state law unless they interfere with federal policy. ${ }^{183}$ This ambiguity has left the lower courts free to use either state or federal law to characterize federal claims for borrowing purposes. Consequently, prior to Wilson and Malley-Duff there had been considerable variation among the circuits in their choice of a federal or state approach to characterizing a particular federal right, as well as varia-

${ }^{188}$ See Malley-Duff, 107 S. Ct. at 2762.

${ }^{189}$ Id. (citing Wilson v. Garcia, 471 U.S. 261, 269-70 (1985)). Justice Stevens' opinion in Wilson, however, conveyed a mixed message. He seemed to acknowledge the substantive statute ( $(1983)$ as the basis for this characterization process, but he also cited 42 U.S.C. $\S 1988$ as authority for this analysis. He wrote:

The characterization of $\S 1983$ for statute of limitations purposes is derived from the elements of the cause of action, and Congress' purpose in providing it. These, of course, are matters of federal law. Since federal law is available to decide the question, the language of $\S 1988$ directs that the matter of characterization should be treated as a federal question.

Wilson, 471 U.S. at 268-69.

A similarly mixed message involving $\S 1988$ was delivered in Board of Regents v. Tomanio, 446 U.S. 478, 488-89 (1980) (quoting Robertson v. Wegmann, 436 U.S. $584,594 \mathrm{n.11}(1978)$ ). It seems fairly clear from the Court's analyses in both Wilson and Tomanio that $\S 1988$ may be regarded as a codification of a general presumption to borrow state law. See also Johnson v. Railway Express Agency, 421 U.S. 454, 464 (1975) ( $\$ 1988$ may require courts to apply state law); Time Bars, supra note 76, at 1041 n.138 (same). But Justice Stevens also qualified the borrowing presumption: "Congress surely did not intend to assign to state courts and legislatures a conclusive role in the formative function of defining and characterizing the essential elements of a federal cause of action." Wilson, 471 U.S. at 269.

190383 U.S. 696 (1966).

191 Id. at 706.

192 See Time Bars, supra note 76, at 1057-58 \& nn.195-96.

${ }^{193}$ See Hoosier Cardinal, 383 U.S. at 706. 
tion within circuits and districts in characterizing different federal rights. ${ }^{194}$

The problems posed by characterizing the claim have been an important aspect of the debate regarding the appropriate limitations period for civil RICO. This debate has revolved around the question of whether the appropriate period should be identified by directly analogizing the predicate offenses to the causes of action recognized in the states' general statutes of limitations, or by characterizing the entire RICO claim as a matter of federal law and then ascertaining an analogous state statutory period. ${ }^{195}$

The former approach has been more popular. ${ }^{196}$ It involves selecting the state statute of limitations for the offense that is most similar to the predicate offenses alleged as part of the RICO claim. ${ }^{197}$ In addition to securities, mail, and wire fraud, more than twenty-five federal statutory crimes and nine state law felonies may serve as RICO predicates. ${ }^{198}$ When a court adopts this approach to characterization, the categories of the state's limitation law provide the guidelines for classifying each RICO complaint. Because of the pivotal role played by predicate offenses in the characterization process, this approach allows the RICO time bar to vary from case to case within a state, as well as among the states.

In contrast, when the Third Circuit characterized Malley-Duff's complaint, it was concerned with finding "a broader analogy that could encompass all claims brought thereunder," an 'approach the district court had rejected. ${ }^{109}$ The court reasoned that the alleged fraud was only one element of the RICO claim. Other predicate offenses, as well as the alleged enterprise and pattern elements of RICO were essential to the complaint. As the Third Gircuit noted, "[c]oncepts such as RICO

104 See generally Time Bars, supra note 76, at 1059-64 (discussing differences within and between circuits in selecting statutes of limitation for cases arising under the Labor-Management Relations Act (LMRA), the Labor-Management Reporting and Disclosure Act (LMRDA), the Givil Rights laws, the Securities Exchange Act of 1934, SEC Rule 10b-5, and the Military Selective Service Act); supra note 86 and accompanying text. Lower courts, however, tend either to assert by rote that characterization is a federal question, or fail to discuss the characterization process at all. See Time Bars, supra note 76, at 1064-65 \& nn.240-41.

198 See ABA TASK FORCE REPORT, supra note 150, at 389-90.

${ }_{188}$ See id. at 389-90 \& nn.635-37.

197 For example, both Malley-Duff parties construed the RICO claim as fraud, based on the actions alleged as predicate offenses. See Malley-Duff v. Crown Life, 792 F.2d at 344.

198 See 18 U.S.C. $\S 1961$ (1982 \& Supp. IV 1986); A.J. Cunningham Packing Corp. v. Congress Fin. Corp., 792 F.2d 330, 337 (3d Cir. 1986) (Sloviter, J., concurring).

${ }^{199}$ Malley-Duff v. Crown Life, 792 F.2d at 346-47. 
'enterprise' and 'pattern of racketeering activity' were simply unknown to common law, and all federal crimes contain jurisdictional and other elements irrelevant to any state civil action. Thus . . . any analogies to traditional state causes of action 'are bound to be imperfect.'

The Court agreed with the Third Circuit that "there is no comparable single state law analogue to RICO. . . . [T] he predicate acts that may establish racketeering activity under RICO are far ranging, and . . . cannot be reduced to a single generic characterization."201 Moreover, with regard to the more general question of characterizing federal claims, the Court also indicated that "in determining the appropriate statute of limitations, the initial inquiry is whether all claims arising out of the federal statute 'should be characterized in the same way, or whether they should be evaluated differently depending upon the varying factual circumstances and legal theories presented in each individual case." "202 This provides lower courts with an unambiguous statement that the policy embodied in the federal statute is the cornerstone of the characterization process: "The characterization of a federal claim for purposes of selecting the appropriate statute of limitations is generally a question of federal law. . . ."203

\section{Borrowing an Appropriate Limitations Period}

"[T]he next inquiry is whether a federal or state statute of limitations should be used."204 The Court's analysis of the second phase of the process offers two sources of authority for the familiar presumption that state limitations statutes should be consulted. First, the Court noted: "We have held that the Rules of Decision Act requires application of state statutes of limitations unless 'a timeliness rule drawn from elsewhere in federal law should be applied." "20s The second rationale

200 Id. at 348 (quoting Wilson v. Garcia, 471 U.S. 261, 272 (1985)). Regarding this problem the ABA Task Force argued that "RICO is manifestly directed towards activities that go beyond the mere commission of predicate offenses." ABA TASK FORCE REPORT, supra note 150, at 390-91.

201 Malley-Duff, 107 S. Ct. at 2765.

${ }^{202} I d$. at 2762 (quoting Wilson, 471 U.S. at 268). The Ninth Gircuit recently held that the general federal statute of limitations, see supra note 80 , applied to citizen enforcement suits brought under the Clean Water Act. The court maintained that the shorter state limitations period would frustrate the federal policy of allowing citizens to serve as private attorneys general and would create non-uniformity among states. See Sierra Club v. Chevron U.S.A., 834 F.2d 1517, 1521 (9th Gir. 1987).

${ }^{203}$ Malley-Duff, $107 \mathrm{~S}$. Ct. at 2762.

204 Id. at 2762 .

208 Id. at 2762 (citation omitted) (quoting DelCostello v. International Bhd. of Teamsters, 462 U.S. 151, 159 n.13 (1983)). Although the Court does not develop this argument, some commentators have strongly defended the position that the Rules of Decision Act (RDA) requires the judiciary to consult state law. See P. KuRLand, 
invokes the implicit intent of the Congress that enacted the law without a limitations period: "Given our longstanding practice of borrowing state law, and the congressional awareness of this practice, we can generally assume that Congress intends by its silence that we borrow state law."208 The remainder of the borrowing analysis is an examination of suitable reasons for deviating from this "longstanding practice." The Court focused on the issues surrounding the implementation of RICO, citing precedents in which "our characterization of [the] federal claim has led the Court to conclude that 'state statutes of limitations can be unsatisfactory vehicles for the enforcement of federal law.' "207 The Court noted the lack of a suitable state analogy, ${ }^{208}$ as well as the practical problems and unnecessary litigation costs created by the lack of uniformity discussed by the ABA Task Force. ${ }^{209}$ The Court then turned to the legislative history of RICO and parallels to the antitrust laws that would support "borrowing" the four year limitations provision from the Glayton Act, which "provides a far closer analogy than any availa-

Politics, the Gonstitution, AND THe WarRen Court $62-63$ (1970); Merrill, supra note 14, at 27-32; cf. Comment, Rules of Decision in Nondiversity Suits, 69 YALE L.J. 1428, 1431-34 (1960) (recognizing that the RDA seemed to require that federal judges consult state law, but pointing out "three phrases [in the Act that] might be construed to restrict the scope of state law."). Early decisions summarily dealt with the statute of limitations question by citing the RDA as grounds for applying state law. See, e.g., Campbell v. Haverhill, 155 U.S. 610, 614-15 (1895) (citing the RDA for application of a state general statute of limitations); M'Cluny v. Silliman, 28 U.S. (3 Pet.) 270, 277 (1830) (same).

The Act provides: "The laws of the several states, except where the Constitution or treaties of the United States or Acts of Congress otherwise require or provide, shall be regarded as rules of decision in civil actions in the courts of the United States, in cases where they apply." 28 U.S.C. $§ 1652$ (1982). The qualifying phrase, "in cases where they apply," does not mandate application; rather, the court must first determine whether state law applies. Federal common law is by definition a rule of decision made by a court when the cause of action is federal, and no express statutory provision-federal or state-applies of its own force. Moreover, the RDA specifically excepts civil actions when federal law "otherwise require[s] or provide[s]." Thus, a federal policy interest expressed in a statute provides the initial ground for determining whether state law should be consulted. With regard to federal common law, once a court has determined that state law does not apply of its own force, and that the federal policy expressed in the statute warrants a uniform federal rule of decision, the RDA does not apply. But see Burbank, Interjurisdictional Preclusion, Full Faith and Credit, and Federal Common Law: A General Approach, 71 CoRnell L. Rev. 734, 758-762 (1986) (arguing that the RDA is federal statutory law that the Court must consider in making federal common law.); id. at 761 ("The real problem with taking the Rules of Decision Act seriously, as an original proposition, is that the standards for the creation of federal common law suggested in the Act may be thought inadequate to the needs of the federal government, including those of the federal juduciary.").

${ }^{206}$ Malley-Duff, 107 S. Ct. at 2762.

${ }^{207}$ Id. at 2762 (quoting DelCostello, 462 U.S. at 161).

${ }^{208}$ See id. at 2762-63.

209 See $i d$. at 2763-64. 
ble state statute."210 While the Court approvingly cited the Third Circuit's use of Wilson v. Garcia to argue for a uniform characterization of the claim for borrowing purposes, ${ }^{211}$ the Court rejected the lower court's use of the state catchall statute. ${ }^{212}$ Because not all states have catchall residual statutes of limitation, ${ }^{213}$ the Third Circuit analysis would be unsuited to those states. "Any selection of a state statute of limitations in those States without a catch-all statute would be wholly at odds with the . . . sui generis nature of RICO."214

In the final element of the borrowing analysis, the Court rejected the notion of borrowing the five year statute of limitations for criminal RICO prosecutions. After noting that Congress did not select this period explicitly for RICO, but relied instead on the catchall federal criminal limitations period, the Court concluded: "[T]he 5-year statute of limitations for criminal RICO actions does not reflect any congressional balancing of the competing equities unique to civil RICO actions or, indeed, any other federal civil remedy."215 The borrowing phase of the Court's analysis thus involves considering three distinct sets of concerns: 1) the Court's longstanding practice of borrowing state law; 2) the underlying policy interests and practical considerations involved in implementing the statutory remedy enacted by Congress; and, 3) the equitable policies served by statutes of limitations.

\section{Justice Scalia's Concurrence}

While Justice Scalia concurred in the judgment of the Court, he declined to join the opinion, stating that it was "a giant leap into the realm of legislative judgments." ${ }^{216}$ He concluded: "[W]hile I can accept the reasons the Court gives for refusing to apply state statutes of limitations to the civil RICO claim at issue here, .. . I would hold that if state codes do not furnish an 'appropriate' limitations period, there is

210 Id. at 2767.

213 See id. at 2763.

212 See id. at 2765 . The choice of a uniform statute within each state would have been consistent with the Court's approach in Wilson, 471 U.S. at 265-66. Combining the strong "characterization" analysis from Wilson with the essentially policy-based arguments for a federal rather than state limitations period in DelCostello, 462 U.S. at 158-59 \& n.13, is what ultimately distinguishes the Court's position in Malley-Duff.

${ }^{213}$ Kentucky, for example, has no catchall provision. See Ky. REv. STAT. ANN. ch. 413 (Michie/Bobbs-Merrill 1972 \& Supp. 1986).

${ }_{214}$ Malley-Duff, 107 S. Ct. at 2765 (citing A.J. Cunningham Packing Corp. v. Congress Fin. Corp., 792 F.2d 330, 339 (3d Gir. 1986) (Sloviter, J., concurring)).

215 Id. at 2767. Such an analysis of "competing equities" refers to the policy interests served by limiting particular causes of action, rather than the policies underlying the remedy itself. See supra notes 88-94 and accompanying text.

${ }^{216}$ Malley-Duff, 107 S. Ct. at 2767 (Scalia, J., concurring). 
none to apply."217 Consequently, because there is no statute of limitations on civil RICO claims, Malley-Duff's claim was not time barred. $^{218}$ Justice Scalia's conclusion was based on a rejection of the Court's view of its role in determining federal statutes of limitations, rather than on a competing analysis of the legal issues and findings of fact in the case before the Court.

After analyzing the Court's decisions borrowing state statutes of limitations in two early cases, M'Cluny v. Silliman ${ }^{219}$ and Campbell $v$. Haverhill, ${ }^{220}$ Justice Scalia proposed a two-part approach to the question, which derives from a "theory about the application of state statutes of limitations to federal statutory causes of action."221

\section{State Law Applies of Its Own Force}

Justice Scalia's analysis of M'Cluny and Campbell led him to conclude that state statutes of limitations apply to federal claims "as a matter of state law."222 It is the authority of state law that directs that general statutes of limitations apply to federal claims, unless Congress explicitly preempts state law. ${ }^{223}$ This means that when a federal statute provides no limitation period, the first phase of Justice Scalia's analysis is purely a question of state law, and state law applies of its own force, or ex proprio vigore. ${ }^{224}$

217 Id. at 2774 .

218 It is not clear from Justice Scalia's assertion whether he means to state that there is no limitation on civil RICO actions in general, or whether his reference to "the civil RICO claim at issue here," is intended to restrict the finding of no limitations period to actions that are substantially similar to the circumstances presented in Malley-Duff. However, the passage in the Court's opinion to which he favorably refers, id. at 2765-66, discusses the general inapplicability of state statutes to federal civil RICO, suggesting that his conclusion is a generalization.

21028 U.S. (3 Pet.) 270 (1830).

220155 U.S. 610 (1895).

${ }^{221}$ Malley-Duff, 107 S. Ct. at 2770 (Scalia, J., concurring).

222 Id. at 2770 .

${ }^{223}$ Id.

224 Because identifying the relevant limitations period is a state law question, presumably state laws governing accrual, commencement, tolling, and conflicts of laws would govern this phase of the analysis. See supra notes 87, 103-06 and accompanying text. Curiously, in view of his state law analysis, Justice Scalia joined the majority opinion in West v. Conrail, 107 S. Ct. 1538 (1987), which was decided two weeks before Malley-Duff was argued. In West, Justice Stevens wrote for a unanimous court: "[W]e now hold that when the underlying cause of action is based on federal law and the absence of an express federal statute of limitations makes it necessary to borrow a limitations period from another statute, the action is not barred if it has been 'commenced' in compliance with Rule 3 within the borrowed period." Id. at 1541. The footnote following this passage explicitly distinguishes the comparable problem in diversity jurisdiction, when the underlying cause of action is based on state law. See id. at 1541 n.4. In such a case, the federal court would apply the commencement require- 
Although Justice Scalia did not provide a specific strategy for approaching the task of applying state law, he seemed to envision it as a rather perfunctory one. He writes:

[I]n applying a state statute, we do not really have to make a new legislative judgment. The state legislature will already have made the judgment that, for example, in contract actions, a certain balance should be struck between "protecting valid claims . . . [and] prohibiting the prosecution of stale ones." That judgment will have been made in the knowledge that it will apply to a broad range of contractual matters, some of which the legislature has not specifically contemplated. ${ }^{225}$

This view of "applying a state statute" ignores the interpretive task required to ascertain which state statute applies, and provides no guidance as to how it should be approached. ${ }^{\mathbf{2 2}}$

Moreover, while the state legislature may have understood that its general statute of limitations would be applied to a broad range of common law and state statutory questions, the Court has rejected the assumption that state general statutes of limitations necessarily embody the balance of policy interests required to implement a federal statutory remedy: "State legislatures do not devise their limitations periods with national interests in mind, and it is the duty of the federal courts to assure that the importation of state law will not frustrate or interfere with the implementation of national policies."22z

Rather than allowing the Court to make a single "new legislative judgment" that would apply to the federal statutory cause of action in all courts, applying state law entangles the federal courts in making a "legislative" judgment for each federal case. Requiring trial courts to ascertain which state statute applies of its own force takes the federal courts even deeper into the task of divining state law-a task that has

ments of state law, as well as the limitations period. See Walker v. Armco Steel Corp., 446 U.S. 740, $752-53$ (1980).

${ }^{226}$ Malley-Duff, $107 \mathrm{~S}$. Ct. at 2774 (Scalia, J., concurring) (quoting Johnson v. Railway Express Agency, 421 U.S. 454, 464 (1975)).

${ }^{226}$ As one thorough study of the statutes of limitation problem concluded:

[B]y analogizing courts may create fiction-they may arbitrarily grasp a state period for a federal claim without an appropriate state analogue. Such searching is tantamount to the judicial creation of periods of limitation for federal rights-the same 'bald . . . form of judicial innovation' that the Supreme Court has discouraged.

Time Bars, supra note 76, at 1078 (footnotes omitted) (quoting UAW v. Hoosier Cardinal Corp., 383 U.S. 696, 701 (1966).

${ }^{227}$ Occidental Life Ins. Go. v. EEOG, 432 U.S. 355, 367 (1977). 
been called "one of the most unproductive byproducts of diversity jurisdiction." 228 The first phase of Justice Scalia's inquiry makes this task the focal point for determining the statute of limitations for a federal cause of action, implying that the trial courts' problems in ascertaining which state statute applies are irrelevant to deciding how the Court should approach the question.

Finally, it is not clear what the ex proprio vigore doctrine would mean for future cases arising under the federal statute in which state law had been applied. In the diversity situation, this doctrine prohibits federal court decisions from interfering with the course of state law. Federal determination of state law is not binding precedent on state courts. Should a different result obtain when state law is applying of its own force to federal rights? Consider, for example, a claim based on a federal statute without its own time bar, which the plaintiff filed in a state court with concurrent jurisdiction. Under Justice Scalia's regime, should the state court proceed to characterize the claim and apply its own statute of limitations ex proprio vigore? Or should it, pursuant to the supremacy clause, look to federal precedent characterizing the federal claim in terms of state law? Applying the ex proprio vigore doctrine in the former manner would contradict the well-settled principle that "[o]nce a federal court fills a gap in federal law, the gap-filler, whether judicially-created or absorbed from the state, becomes federal law."228

\section{Has Congress Preempted State Law?}

The second phase of Justice Scalia's analysis is a seemingly straightforward preemption inquiry that accommodates the policy interests underlying the statutory remedy. Congress has the authority under the Constitution to provide limitations for the causes of action it creates, which preempt the states' general statutes of limitations. ${ }^{\mathbf{2 3 0}}$ Justice Scalia argues that congressional silence about limitations provisions may indicate an intent to preempt state law in those situations in which applying the state statutes ex proprio vigore would interfere with

${ }^{228}$ A.J. Cunningham Packing Corp. v. Congress Fin. Corp., 792 F.2d 330, 337 (3d Cir. 1986) (Sloviter, J., concurring).

228 Time Bars, supra note 76, at 1029. This view is supported by the Court's decision in Textile Workers Union v. Lincoln Mills, 353 U.S. 448, 457 (1957) ("state law applied [as part of a federal statutory scheme] will be absorbed as federal law"). Specialized federal common law is binding on the states through the supremacy clause, as is any other federal law. See Hill, The Law-Making Power of the Federal Courts: Constitutional Preemption, 67 Colum. L. Rev. 1024, 1076 (1967); Monaghan, supra note 35 , at 10.

${ }^{230}$ See supra text accompanying notes 78-80. 
the federal policy enacted by Congress. ${ }^{231}$ Thus, while he maintains that congressional intent in enacting the substantive statute and policy considerations in implementing the federal remedy are irrelevant in determining the applicable statute of limitations, the Court may use these considerations to infer an intent to preempt state limitations law.

Preemption by congressional silence, however, merely indicates that there is no limitation on actions when state limitations "frustrate or interfere with the implementation of national policies."232 The policy analysis serves merely to avoid the effects of a burdensome state statute; it does not inform the Court's more complex decision in the first phase regarding which statute to apply. As Justice Scalia stated: "[I]f we determine that the state limitations period that would apply under state law is pre-empted because it is inconsistent with the federal statute, that is the end of the matter, and there is no limitation on the federal cause of action."233 Justice Scalia's preemption analysis relies heavily on the Court's opinion in M'Cluny $v$. Silliman. ${ }^{234}$ In this case the plaintiff's cause of action was based on a right afforded by federal statute ${ }^{235}$ and remedies afforded by the common law of the state of Ohio. ${ }^{236}$ The defense was expiration of the state statute of limitations for actions upon the case. The Court's holding was the concise statement that: "It is a well-settled principle, that a statute of limitations is the law of the forum, and operates upon all who submit themselves to its jurisdiction."237 Based on our earlier analyses, we know that statutes of limitation were law of the forum because they "went to the remedy" rather than the right. ${ }^{238}$ In this case, therefore, the Court did not need to address the question of whether Congress might have intended to place a particular time bar on the right it had created; by leaving the

231 See, e.g., Occidental Life Ins. Co. v. EEOC, 432 U.S. 355, 367-69 (1977) (finding that a six month state limitations period interfered with federal policy because the statute specified that a court action could not be filed until administrative remedies had been exhausted-a process that was lengthier than the state limitations period).

232 Id. at 367.

${ }^{233}$ Malley-Duff, 107 S. Ct. at 2771 (Scalia, J., concurring). Justice Scalia denies that the Court is making any policy determination in deciding what statute of limitations to apply. Either state statutes apply on their own authority, or there is no time bar. But see supra note 10 and accompanying text.

23428 U.S. (3 Pet.) 270 (1830).

235 The plaintiff alleged that the register at the United States land office failed to properly register his purchase of land, in violation of an act of Congress. M'Cluny, 28 U.S. (3 Pet.) at 270.

238 The plaintiff brought "an action upon the case . . . for an act of nonfeasance or malfeasance in office." Id. at 276.

${ }^{237}$ Id. at 276 (emphasis omitted).

238 See supra notes 95-98 and accompanying text; see also Davis v. Mills, 194 U.S. 451, 456 (1904) ("Ordinary limitations of actions are treated as laws of procedure and belonging to the lex fori, as affecting the remedy only and not the right.") 
right to be remedied by common law forms of action, Congress consigned questions of remedies and their limitation to the discretion of the states. As the Court stated: "The action on the case must be brought within six years from the time the cause of action arose, and it is immaterial, what that cause may be; the statute bars the remedy by this form of action, if it be not prosecuted within the time."238 The Court initially observed that it is not necessary for the state to have intended to limit the federal right for the time bar to be effective, ${ }^{240}$ then declared the applicability of the statute to all causes whose characterization brings them within its domain. The quoted passage reiterates the right/remedy distinction, and clarifies that the state is limiting the remedy. This last point, of course, renders the decision inapplicable to the situation in Malley-Duff, in which Congress has enacted an entirely new treble damages remedy that was, as the Court observed, "unknown at common law."241

The M'Cluny Court also invoked the Rules of Decision Act of 1789. ${ }^{242}$ Upon examining the structure of the Court's opinion, it becomes apparent that this statute was used only to counter plaintiff's second contention ${ }^{248}$ - that no state statute of limitations may limit a private cause of action in federal court "where the plaintiff's rights ac-

${ }^{238}$ M'Cluny, 28 U.S. (3 Pet.) at 277 (emphasis added). The Court continued: "By bringing his action on the case, the plaintiff has selected the appropriate remedy for the injury complained of. This remedy, the statute bars. Can the Court, then, by referring to the ground of the action, take the case out of the statute?" Id. at 278 . By so carefully distinguishing right and remedy, the Court did not need to address the issue of interstitial lawmaking, that is, whether the policy expressed in the substantive statute requires a time bar. The remedy carries its own limitation that is fully with the judicial purpose served by time bars of ensuring that courts need not adjudicate stale claims. See supra notes 90-91 and accompanying text.

240 Justice Scalia cited Campbell v. Haverhill, 155 U.S. 610 (1895), for this proposition, see Malley-Duff, $107 \mathrm{~S}$. Ct. at 2769, apparently agreeing that the right/remedy distinction in $M^{\prime}$ 'Cluny bars regarding the Court's assertion as an unambiguous statement that states have power to limit federal rights. Notwithstanding the parties' briefs in these early cases, the Court does not seem to have entertained the proposition that the states' power to limit federal rights was limited by anything other than an express or implied discrimination against the federal right, see Time Bars, supra note $76,1045-55$, or a frustration of the statutory policy because state time bars were too short or too long.

241 Malley-Duff, 107 S. Ct. at 2764 (citing A.J. Cunningham Packing Corp. v. Congress Fin. Corp., 792 F.2d 330, 348 (3d Cir. 1986)).

${ }^{242}$ Judiciary Act of 1789 , ch. $20, \S 34,1$ Stat. 92, (codified as amended at 28 U.S.C. § 1652 (1982)); see supra note 205.

213 The first contention was that the statute of limitations provided for the common law remedy, and did not apply to the cause of action. Neither the plaintiff's argument, nor the Court's reference to the settled principle of applying the law of the forum, mentioned the federal source of the right. See $M^{\prime} C l u n y, 28$ U.S. (3 Pet.) at 272, 276. 
crued to him under a law of Congress."244 If the Court regarded the principle of lex fori as adequate grounds for the judgment that the general statute of limitations was applicable to the state law remedy, why did it take the extra step of demonstrating congressional intent (via the RDA) that state law (presumably including statutes of limitation) applied to federal causes of action? ${ }^{245}$

Had the Court declared in 1830, that the choice of an applicable statute of limitation for federal causes of action was governed by the procedural law of the forum (as was the case when states' laws were in conflict), ${ }^{248}$ the federal courts would have been required to adhere to the regressive strictures of the Process Act of 1789, and subsequent Process Acts. ${ }^{247}$ This Act, like the Rules of Decision Act, mandates conformity with state law, but it specifies that federal procedure will conform to the procedure the state courts used in 1789 , or as of the date of their admission to the Union. The later Acts specified conformity to state procedure as of 1828 , and then as of 1842 . The mayhem produced by this static form of conformity was not rectified until Congress passed the Conformity Act of 1872 which required federal conformity with current, evolving state procedure. ${ }^{248}$

As regards plaintiff's position in $M^{\prime}$ Cluny that state statutes of limitation did not apply to congressionally created rights, the application of either the newly revised Process Act of 1828, or the Rules of Decision Act of 1789, would have given the same answer: state law governed the limitation on the remedy. Given the acknowledged "quasiprocedural" character of statutes of limitations, ${ }^{249}$ perhaps the Court chose to simplify the matter by attending to the substantive impact of

244 Id. at 276.

24 Unlike some commentators, see supra note 205, Justice Scalia does not believe that the RDA forms any part of the rationale for state law applying of its own force. Rather, he regards the Act as support for the presumption that Congress intends that the Court apply state law when the substantive statute is silent. See Malley-Duff, 107 S. Ct. at 2769 . This presumption may be rebutted only by contrary evidence of congressional intent, or evidence that applying state law would discriminate against the federal statutory scheme. See infra text accompanying notes 281-93.

${ }^{248}$ If the Court had not addressed the second contention, this would have been the logical implication of the Court's holding that the state remedy and (admittedly procedural) statute of limitation applied to a federal cause of action.

${ }_{247}$ See Tunks, Categorization and Federalism: "Substance" and "Procedure" After Erie Railroad v. Tompkins, 34 ILL. L. REv. 271, 274 (1939). But see Burbank, supra note 109, at 1037 n.90 (noting that the Process Act of 1792 allowed courts to make "alterations and additions" in conforming their procedure to state law).

248 See C. Hepburn, The Historical Development of Code Pleading in AMERICA AND ENGLAND 152-53 (1897); see also Blume \& George, supra note 81, at 966-83 (discussing the differential treatment of statutes of limitation before and after 1872).

249 See HART \& WechSLER, supra note 28 , at 825. 
general statutes of limitations on federal rights, rather than relying on the states' characterization of their general statutes of limitations as procedural for conflict of laws purposes. ${ }^{250}$ In effect, the M'Cluny Court was "characterizing" the claim in terms of the federal statute, as the Court did in Malley-Duff. That is, the gap that was filled by state law in M'Cluny encompassed both remedy and limitation. Had Congress enacted a remedy and a limitation, it would have been a "substantive" rule according to then-current limitations practice. ${ }^{251}$ Accordingly, it is reasonable to have applied the RDA rather than the Process Act to declare that state substantive law can apply to a federal cause of action.

Justice Scalia maintained in Malley-Duff that the decision in $M^{\prime}$ Cluny did not turn on this right/remedy distinction. ${ }^{262}$ However, he also limited the M'Cluny Court's Rules of Decision Act reasoning to serving as "confirmation of [Ohio's power] where 'no special provision had been made by congress." "253 This congressional confirmation of state power (via the RDA) was his rationale for the presumption against judicial preemption of states' general statutes of limitations. This interpretation stands in rather marked contrast to subsequent decisions which cited M'Cluny's holding regarding the Rules of Decision

${ }^{250}$ See supra note 106. This is not an argument that the Court was mistaken in applying the Rules of Decision Act rather than the Process Acts. To the contrary, it seems to have been an eminently sensible way of addressing plaintiff's claim. The courts were accustomed to using various fictions in construing common law pleadings in order to do justice. While statutes are purportedly to be construed differently than common law, this was not a situation in which the literal words of the statute offered the Gourt a clear mandate to choose one act over another. Statutory construction required the Court to use its judgement to determine whether general statutes of limitation were procedural (as they were in contemporary state conflict of laws practice), or substantive (as they would have been had Congress enacted its own substantive time bar with the right). This is the same argument that Professor Weintraub has recently made regarding conflicts of laws analysis. See R. Weintraub, supra note 106 , at $\S 3.2 \mathrm{C} 2$.

251 See supra text accompanying notes 101-05.

${ }^{262}$ See Malley-Duff, 107 S. Ct. at 2769 (Scalia, J., concurring).

${ }^{263} I d$. (quoting M'Cluny, 28 U.S. (3 Pet.) at 277). Given the important distinction between substantive time bars and general statutes of limitations in court proceedings during that period, this phrase is more likely to refer to Congress's failure to provide a substantive time bar, than to a congressional presumption that its silence is an affirmative directive to federal courts not to preempt state law as Justice Scalia maintains. See id. at 2770-71.

As discussed above, it was widely understood that congressional specification of a substantive time bar preempted the general statutes of limitations specified by the state. See supra text accompanying note 78. The full text of the passage in question reads: "Under [the Rules of Decision Act], the acts of limitations of the several states, where no special provision has been made by Congress, form a rule of decision in the Courts of the United States, and the same effect is given to them as is given in the state Courts." M'Cluny, 28 U.S. (3 Pet.) at 276. Although the difference in emphasis may seem minor, this presumption against preemption by silence forms a major element of Justice Scalia's critique of the Court's discretion analysis. 
Act as authority for almost mechanically applying state general statutes of limitation to federal causes of action. ${ }^{254}$

\section{Implications of Differing Meta-legal Orientations}

The opinions discussed in Part II of this Comment not only differ, they both present more than one argument, and each argument reflects a slightly different meta-legal orientation. In Part I we discussed three elements of a meta-legal framework. ${ }^{255}$ These elements pertain to a Justice's view of the Court's role in dispute resolution, law declaration, and institutional guardianship. Four different arrangements of these elements offer a way of understanding the Agency Holding Corp. $v$. Malley-Duff $\mathcal{E}$ Associates, Inc., ${ }^{256}$ opinions. Two of these frameworks are required to account for the different arguments made in the Court's opinion; the other two underlie the concurrence's vacillation between acquiescing to the Court's reasoning and attacking it.

\section{A. Statutory Patchwork}

The organizing principle of the "statutory patchwork" approach is a pragmatic view of federal common law as an interstitial "patch" holding together a congressional statute. At one level, the Malley-Duff majority opinion resembles this no-nonsense approach: the Court's dispute resolving function, and its administrative responsibility for the institutional efficacy of the trial courts, take precedence over any particular theory of law. The Court's view of its relation to Congress involves a cooperative willingness to fill in the details omitted by Congress so that disputants-and the lower courts-will not be left to flounder. ${ }^{257}$ What is salient in the Court's reasoning is its focus on the practical difficulties faced by the trial courts in resolving disputes arising under RICO. ${ }^{258}$ The Court does not emphasize the details of this particular dispute; instead, it examines the policies behind RICO and the impossible task of "characterization" faced by trial courts in states that lack a catchall limitations period. ${ }^{258}$ Possible federalism concerns (created by

264 See generally DelCostello v. International Bhd. of Teamsters, 462 U.S. 151, 172-73 \& n.1 (1983) (Stevens, J., dissenting) ("For the past century federal judges have 'borrowed' state statutes of limitations, not because they thought it was a sensible form of 'interstitial law making,' but rather because they were directed to do so by the Congress of the United States." (citing the Rules of Decision Act)).

${ }_{2 \mathrm{SB}}$ See supra text accompanying notes 117-44.

258107 S. Ct. 2759 (1987).

257 See id. at 2763.

${ }^{258}$ See id. at 2765-66.

258 See id. at 2765. 
the slighting of state statutes of limitations) are not mentioned; separation of powers problems (raised because Congress left the courts too much discretion in ascertaining the timeliness of civil RICO claims) are ignored; and problems in legal theory (posed by transforming a longstanding practice of borrowing from state general limitations statutes into grounds for borrowing time bars from federal statutes) are subordinated to the practical considerations of administering justice under the statutory scheme. ${ }^{260}$

This view of the Court's common law making function is a modest, practical one. Federal common law is merely a "temporary" judicial solution to a legislative problem. ${ }^{261}$ But given the exigencies of legislation, the Court is aware that a judicial solution, like a "temporary" road patch, may have to serve for an indefinite period. ${ }^{262}$ There are many good reasons for the legislature to leave statutory gaps, ${ }^{263}$ and many of them have to do with judicial administration of disputes arising under a new statute. ${ }^{264}$ Because the policy considerations underlying statutes of limitations are intimately concerned with the convenience, efficiency, and accuracy of the judicial process, it behooves the Court to proffer a common law rule with considerable care.

This rather pragmatic view of the Court's role in administering

${ }^{260}$ See id. at 2764.

281 "Inevitably our resolution of cases or controversies requires us to close interstices in federal law from time to time ....." West v. Conrail, 107 S. Ct. 1538, 1542 (1987) (Stevens, J., writing for a unanimous court.).

${ }^{262}$ However, judicial "solutions" to the statute of limitations gap have been overturned by statute. Compare Act of May 14, 1947, ch. 52, $\S 6,61$ Stat. 84, 87 (codified at 29 U.S.C. $\$ 255(a)(1982)$ ) (providing a two year limitation for actions for minimum wages and overtime under the Fair Labor Standards Act) with Mid-Continent Petroleum Corp. v. Keen, 157 F.2d 310, 316 (8th Cir. 1946) (applying the five year Iowa state statute of limitations on written contracts in a Fair Labor Standards Act claim for unpaid overtime compensation); compare Act of July 7,1955 , ch. $283, \S 4 \mathrm{~B}$, 69 Stat. 282, 282, (codified at 15 U.S.C. $§ 15(\mathrm{~b})(1982)$ ) (providing a four year limitation for treble damages actions brought under the Clayton Act) with Crummer Co. v. DuPont, 223 F.2d 238, 244 (5th Cir. 1955) (applying Florida's three year statute of limitations) and Sun Theatre Corp. v. RKO Radio Pictures, Inc., 213 F.2d 284, 288 (7th Cir. 1954) (applying Illinois' two year limitations period).

${ }^{263}$ For example, at one time legislators favoring lenient administration of time bars for a preferred statutory scheme would have been well-advised to enact statutes without limitations periods, because courts refused to apply judicially created savings clauses and tolling provisions when the legislature specified its own time bar. See supra notes 99-105 and accompanying text. The courts reasoned that the legislature, having enacted a specific time bars that preempted the general statute of limitations, and remained silent regarding the plethora of subsidiary issues, "intended" to preempt them as well.

${ }^{264}$ Until the EEOC administrative review process was implemented, for example, it would have been difficult to estimate what limitations period would suffice to allow plaintiffs to comply with the statutory requirement that administrative remedies be exhausted prior to seeking court action. See Occidental Life Ins. Co. v. EEOC, 432 U.S. $355,372-73$ (1977). 
federal statutes is of relatively recent origin. Prior to 1875 and the creation of general federal question jurisdiction, ${ }^{\mathbf{2 6 5}}$ the preponderance of cases in federal trial courts were claims arising under patent law or federal pension law, or were claims to enforce state or federal rights that had been brought to federal court based on diversity of citizenship. ${ }^{268}$ Thus, there was no special affinity between the federal trial courts and the statutory rights enacted by Congress. As Hart and Wechsler assert, "it was not until the consolidation of national sentiment after the Givil War that the basic change was made whereby the national courts became the primary forum for the vindication of federal rights." ${ }^{267}$ Absent a jurisdictional grant in the substantive statute, any uniformity in administering a nationwide scheme prior to 1875 came about through appeals to the Supreme Court from the decisions of state courts. Clearly, as Congress began to enact more and varied national programs, it would have been virtually impossible for the appeals process to have accommodated any form of nationwide uniformity in statutory construction. ${ }^{288}$

After the grant of federal question jurisdiction made it possible to involve trial courts in interpreting federal statutory schemes, the Court developed a very reasonable borrowing "rule of thumb" for coping with gaps such as time limitations. ${ }^{269}$ The federal common law basis of this approach acknowledges the subordination both of the Court's rule to subsequent changes by Congress, and of the federal courts' analysis of what is needed to fill a statutory gap to borrowed state law. The specific rule developed to fill the gap is, of course, shaped by precedent, judicial assessments of congressional policy, and doctrines of legal interpretation then prevailing on the Court. As Justice Frankfurter stated: "The implied absorption of State statutes of limitation within the interstices of the federal enactments is a phase of fashioning remedial details

${ }^{285}$ See Act of March 3, 1875, ch. 137, § 1, 18 Stat. 470, 471 (codified as amended at 28 U.S.C. $\S 1331$ (1982)); F. FrankfurTer \& J. LANDIS, The Business OF THE SUPREME COURT 64-65 (1928).

${ }_{268}$ While the patent and pension laws contained their own jurisdictional grants, the Judiciary Act of 1789 gave the district courts original (and exclusive) jurisdiction of suits in admiralty, and suits against consuls and vice consuls. It provided for concurrent jurisdiction with the states of cases in which an alien sued in tort. See HarT \& WECHSLER, supra note 28 , at $33-34,845$.

${ }^{267}$ Id. at 844-45.

${ }^{288}$ Cf. Frankfurter, Distribution of Judicial Power Between United States and State Courts, 13 Cornell L. Rev. 499, 499-507 (1928) (discussing the relation between the scope of federal jurisdiction, the size of the Court's docket, and the Court's ability to address the "great issues of government"). Arguably, the problem is even greater in our day. See G. CALABRESI, supra note 135, at 1-30.

${ }^{269}$ See DelCostello v. International Bhd. of Teamsters, 462 U.S. 151, 158 n.12 (1983). 
where Congress has not spoken but left matters for judicial determination within the general framework of familiar legal principles."270

\section{B. Patchwork in the Seamless Web of Law}

In contrast to the dominating pragmatism of the Court's opinion, one reading of the Malley-Duff concurrence suggests that the latter is solidly based on a theory of law and an analysis of the judiciary's institutional role in ensuring that the law promulgated by Congress and the courts conforms to that theory. The meta-legal emphasis, therefore, is on the legal theory and the institutional guardianship required to sustain that theory, while very little attention is paid to the particular dispute at bar, the statutory scheme enacted by Congress, or the trial courts' difficulties in adjudicating disputes that arise under that scheme.

The particular theory of law that informs this analysis focuses on the unique federalism concerns that result from the duality of our federal and state legal systems. One of the responsibilities of the federal judiciary as an institutional guardian is attending to the relations between the two. ${ }^{271}$ While the Malley-Duff concurrence did not discuss federalism concerns, the opinion employed a legal theory that assigns priority to state law in order to analyze the Court's prior practices. ${ }^{\mathbf{2 7 2}}$ For example, the opinion summarily concluded that state law applies unless preempted. This is a conclusion derived from theory, rather than an analysis of the statute and legal precedent; there is no suggestion as to how one would go about ascertaining the applicable state limitations statute for a civil RICO case. Indeed, the last paragraph of the concurrence merely accepts "the reasons the Gourt gives for refusing to apply state statutes of limitations to the civil RICO claim at issue," $" 273$ as a basis for concluding that there is no time bar. Certainly, this offhand acceptance of the Court's rather complex construction of the statute, its underlying purpose, and the practicalities involved in implementing

270 Holmberg v. Armbrecht, 327 U.S. 392, 395 (1946).

${ }^{271}$ See O'Connor, Our Judicial Federalism, 35 CASE W. RES. L. Rev. 1, 4 (1984) ("[B]asic facts about our judicial federalism indicate the need for some means to assure a consistent and uniform body of federal law among the state and federal courts."); see also Freund, Umpiring the Federal System, 54 Colum. L. REv. 561, 578 (1954) ("The rôle of the courts in maintaining a working federalism is precisely this task of mediation between large principles and particular problems, the task of interposing intermediate principles more tentative, experimental and pragmatic."). In Justice Frankfurter's words: "Like all courts, the federal courts are instruments for securing justice through law. But unlike most courts, they also serve a far-reaching political function. They are a means . . . for achieving the adjustments upon which the life of a federated nation rests." Frankfurter, supra note 268, at 500.

${ }^{272}$ See Malley-Duff, 107 S. Ct. at 2768-71 (Scalia, J., concurring).

${ }^{273}$ Id. at 2774 (Scalia, J., concurring). 
it-especially in the wake of a lengthy and contentious criticism of the Court's approach to the problem-suggests that Justice Scalia's objection to the majority's approach is not an objection to policy analysis in its own right. It is, rather, based on a theoretical predisposition that obviates legal analysis.

Certain elements of the concurrence indicate strong ties to the well-known grand theory of law promulgated by Hart and Wechsler:

Federal law is generally interstitial in its nature. It rarely occupies a legal field completely, totally excluding all participation by the legal systems of the states. . . . Federal legislation, on the whole, has been conceived and drafted on an ad hoc basis to accomplish limited objectives. It builds upon legal relationships established by the states, altering or supplanting them only so far as necessary for the special purpose. Congress acts, in short, against the background of the total corpus juris of the states in much the same way that a state legislature acts against the background of the common law, assumed to govern unless changed by legislation. ${ }^{274}$

Note that in this exposition of the theory, the word "interstitial" in the first sentence completely inverts the problem of interstitial lawmaking as it is described in the Court opinions we have examined. Rather than the Court's oft-restated concern with filling the interstices of congressional statutes, Professors Hart and Wechsler indicate that congressional statutes are filling the interstices in state law. ${ }^{275}$ This theory completely transforms the analysis of what the Court is doing in filling statutory gaps by "making" common law. Suddenly, because state law (and the web of common law it augments) surrounds and underlies congressional action, a "gap" in a statute is not a hole that must be filled by the Court; it is a window that allows the underlying state law to be seen.

Strictly construed, such a metatheoretical view of the law accounts for Justice Scalia's assertion that state law applies of its own force in the statutory gaps. ${ }^{276} \mathrm{His}$ critique of the Court's approach is based on

274 HART \& WECHSLER, supra note 28 , at $470-71$.

275 See id. There are three salient characteristics of this view: 1) federal law is localized and specific, while state law is presumed to be the universalizing background; 2) Congress acts with limited objectives, and by implication, states' statutes are intended to be more general; 3) state law, but not federal law, is augmented by and united with the extant body of general common law.

${ }_{276}$ See Malley-Duff, 107 S. Ct. at 2771 (Scalia, J., concurring). The assertedly limited scope of national legislation, however, is difficult to argue as an empirical matter. As Justice O'Connor observed: "The expansion and integration of the national economy brought with it a coordinate expansion in the scope of national problems. This 
the idea that this view was correctly applied in M'Cluny $v$. Silliman ${ }^{277}$ in 1830, and in Campbell v. Haverhill ${ }^{278}$ in 1895, but that the Court's practices unaccountably strayed from this correct view in subsequent decisions. ${ }^{278}$ Thus, Justice Scalia maintains that the Court has been applying state statutes of limitations for the "wrong" reason for a considerable period of its history..$^{280}$

Justice Scalia's analysis of the specific problem presented by the case at bar stems from two assumptions that tacitly structure this universalizing web of law. First, the asserted primacy of state law supplies a presumption that a state general limitations statute applies to whatever statutory right the court is considering, unless Congress intended to preempt it. Policy analysis and legislative history are decidedly secondary; they are relevant only to rebut the presumption that state law applies.

Secondly, because Congress acts on the basis of enumerated powers while state legislatures exercise plenary powers, Justice Scalia attributes different intents to the two bodies. For example, he rejects the Court's choice of a federal time bar, noting that "[f]ederal statutes of limitations ... are almost invariably tied to specific causes of action."281 $\mathrm{He}$ attaches considerable importance to this "particularity" of federal statutes of limitations, contrasting it with the generality of state statutes of limitations, "each of which was intended by the state legisla-

Court has been increasingly generous in its interpretation of the commerce power of Congress, primarily to assure that the National Government would be able to deal with national economic problems." Garcia v. San Antonio Metro. Transit Auth., 469 U.S. 528, 583 (1985) (O’Connor, J., dissenting).

27728 U.S. (3 Pet.) 270 (1830). But see supra text accompanying notes 234-54. 278155 U.S. 610 (1895).

279 See Malley-Duff, 107 S. Ct. at 2771 (Scalia, J., concurring) (implying that in "the second phase of development of the borrowing doctrine" the Court "forg[ot] its origins").

${ }^{280}$ See $i d$. (commenting on the Court's practices over "a century and a half of .. . applying state statutes-first for the right reason, then for the wrong one"). There are other grounds for arguing that courts have been applying state statutes for the wrong reasons that do not support Justice Scalia's conclusions. For example, to the extent that courts have cited the Rules of Decision Act as an affirmative directive to apply state law, see, e.g., Campbell, 155 U.S. at 610, 614 (decided on RDA grounds), they have misconstrued the statute. See DelCostello v. International Bhd. of Teamsters, 462 U.S. $151,159 \mathrm{n.13}$ (1983). It is widely understood that the RDA merely states what would be required of the federal courts in absence of the Act. See Malley-Duff, 107 S. Ct. at 2769 n.1 (Scalia, J., concurring); supra note 205; See generally Fletcher, The General Common Law and Section 34 of the Judiciary Act of 1789: The Example of Marine Insurance, 97 HARv. L. REV. 1513, 1516-27 (1984) (arguing that the RDA functioned as a choice of law statute for federal courts in applying state law, the law merchant, and maritime law).

${ }^{281}$ Malley-Duff, 107 S. Ct. at 2773 (Scalia, J., concurring). 
ture to apply to a whole category of causes of action."282 Because of this universalizing intent of the state legislature, he argues, the Court need not weigh the policy interests expressed in the substantive federal statute:

The state legislature will already have made the judgment that . . . a certain balance should be struck between "protecting valid claims . . [and] prohibiting the prosecution of stale ones." That judgment will have been made in the knowledge that it will apply to a broad range of . . . matters, some of which the legislature has not specifically contemplated. That is not true of a federal statute enacted with reference to a particular cause of action. ${ }^{283}$

Does this analysis hold in light of what we know about the prevailing view of statutes of limitations during the period in which Justice Scalia says the Court was "correctly" applying them, and then applying them for the "wrong" reason?

The starting point for such a distinction is the fact that general statutes of limitations were considered procedural lex fori that went to the remedy, while substantive time bars (such as all federal time limitations on civil actions) were thought to be a condition of the right itself. ${ }^{284}$ We have seen that the Court's holding in M'Cluny $v$. Silliman reflects a composite of a straightforward application of state statutes of limitations as laws of the forum, ${ }^{285}$ and an argument from the RDA that plaintiffs may not claim that states are barred from limiting remedies for the violation of federal rights. ${ }^{286}$ The $M^{\prime}$ Cluny Court explicitly rejected the proposition that the state legislature anticipated the application of its general limitations statute to federal causes of action. ${ }^{\mathbf{2 8 z}}$ (1975)).

$282 I d$.

${ }^{283}$ Id. at 2774 (quoting Johnson v. Railway Express Agency, 421 U.S. 454, 464

${ }^{284}$ See supra text accompanying notes $95-105$.

${ }^{28 s}$ See M'Cluny, 28 U.S. (3 Pet.) at 276-78.

${ }^{280}$ The Court stated:

In giving a construction to this statute [of limitations], where the action is barred by its denomination [as an action on the case], the Court cannot look into the cause of action. They may do this in those cases where actions are barred when brought for causes specified in the statute; for the statute only operates against such actions when prosecuted on the grounds stated.

By bringing his action on the case, the plaintiff has selected the appropriate remedy for the injury complained of. This remedy the statute bars.

Id. at 277-78; see supra notes $242-45$ and accompanying text.

${ }^{287}$ See M'Cluny, 28 U.S. (3 Pet.) at 277. 
The relevant issue was that the state limitation applied to the state common law remedy, and the federal cause of action ${ }^{288}$ was to be remedied by state law. ${ }^{289}$ The Court's RDA analysis merely upholds this linkage of a federal cause of action and a state remedy. ${ }^{200}$

While Justice Scalia does not rest his argument on the RDA, he wants to use this second argument, that state law may limit federal rights, to support the proposition that federal rights must be limited by pertinent state law absent an explicit congressional directive to the contrary. But referring to a hypothetical state legislature contemplating a broad range of actions in enacting a general limitations statute does not support the argument. However diverse the set of actions contemplated by an early legislature in enacting schemes patterned on the common law forms of pleading, their generalized intent does not warrant application of the scheme to civil RICO any more than Congress's intent in enacting a limitation for the Clayton Act warrants such an application. The justification for applying the time limitation in either case is the current Court's legal analysis, which may or may not be aided by speculation about legislative intent. Hypothetical legislative intent does not substitute for the Court's legal analysis-it is merely part of it.

Perhaps more problematic is the fact that the logic of the opinion is consistent with an absolute prohibition on federal common law making. When state law applies of its own force, it is not federal common law. And when federal judges apply state law in this way, they are not establishing federal precedents, they are adjudicating issues as a tribunal of the state. ${ }^{291}$ Because of the impossibility of using this approach as a basis for implementing federal statutes, ${ }^{\mathbf{2 9 2}}$ Justice Scalia provides

288 Plaintiff's stated cause of action was for malfeasance or nonfeasance of a federal officer in failing to register land purchases as required under a federal land act. See id. at 270-71.

288 Plaintiff argued that his cause of action alleged action "ex maleficio," and was not, therefore, an action on the case. See id. at 271-72. "Actions on the case' are associated with actions arising ex contractu; . . . nothing is said in the law of actions ex maleficio." Id. at 273. Had the case been filed today, we might have said that plaintiff was arguing that the statute implied its own, federal remedy. But see Justice Scalia's argument that plaintiff did not raise the question of "whether the federal statute gave him an 'implied right' to sue." See Malley-Duff, 107 S. Ct. at 2769 (Scalia, J., concurring).

280 See M'Cluny, 28 U.S. (3 Pet.) at 277-78.

291 See, e.g., Commissioner v. Estate of Bosch, 387 U.S. 456, 465 (1967) (When "the underlying substantive rule involved is based on state law . . . federal authorities must apply what they find to be the state law . . . . In this respect, [the federal court] may be said to be, in effect, sitting as a state court."); Bernhardt v. Polygraphic Co. of Am., 350 U.S. 198, 203 (1956) ("IA] federal court enforcing a state-created right in a diversity case is . . . in substance 'only another court of the state.' ").

${ }^{292}$ Justice Jackson was highly critical of such a view. He wrote: "Were we bereft of the common law, our federal system would be impotent. . . . Federal law is no 
for an exception when there is a preemption of state law-creating a new domain of federal common law out of whole cloth to patch the statutory gap. Understood in terms of the metaphorical definition of law underlying this view, the statute is thought to have thrust aside the preexisting web of state law, rather than the more usual overlaying of limited federal provisions.

Unlike the view discussed in the following section, Justice Scalia does not appear to require a more or less explicit statement from Congress in order to distinguish such a preemptive situation from the overlay situation. ${ }^{283}$ To the contrary, in the case at bar he was willing to waive this domain into existence by assimilating the Court's policybased inquiry. Without a coherent scheme that relates the policy analysis to the Court's understanding of its task in applying state rules of decision to federal causes of action, however, this form of preemption is precisely the kind of unfettered judicial legislation that is inconsistent with the predictability we expect from our judicial system.

\section{Delegated Legislation}

Viewing federal common law as delegated legislation is the approach criticized by Justice Scalia as the Court's "erroneous" rationale for borrowing state statutes. ${ }^{294}$ Like the statutory patchwork approach, it is marked by the Court's concern with effective administration of the statutory scheme enacted by Congress, but like the seamless web approach, it invokes a legal theory as grounds for the Court's decision, rather than the practicalities of disputes arising under the statute. This approach characterizes one important aspect of the Court's Malley-Duff opinion: it provides the starting point for the "borrowing" phase of the Court's analysis.

Examination of the Court's opinion reveals that it did not fully conform to the more traditional two-step federal common law analysis: the "power analysis," which considers the source and extent of the Court's power in the particular case at bar, and the "discretion analysis" of the relevant factors to be considered in promulgating a common

juridical chameleon, changing complexion to match that of each state wherein lawsuits happen to be commenced . . . . Federal common law implements the federal Constitution and statutes, and is conditioned by them." D'Oench, Duhme \& Co. v. Federal Deposit Ins. Corp., 315 U.S. 447, 470-72 (1942) (Jackson, J., concurring).

${ }_{293}$ While Justice Scalia forcefully argues that an explicit statement by Congress is required to follow the Court's approach of borrowing a time limitation from another federal statute, he does not require the same explicitness in preempting the state's general statute to find that there is no limitation. See Malley-Duff, 107 S. Ct. at 2772-74 (Scalia, J., concurring).

294 See id. at 2768 (Scalia, J., concurring). 
law rule. Rather than fully considering the bases of the Gourt's power to promulgate time limitations for federal statutes, the Court took the congressional origin of the statute whose interstices were to be filled as self-evident grounds for proclaiming that the characterization of a claim is a question of federal rather than state law. ${ }^{295}$ This truncated power analysis, as both Justice Scalia ${ }^{298}$ and the Court ${ }^{297}$ observed, is predicated on a longstanding practice in statute of limitations cases of borrowing state law unless Congress specifically requires otherwise-that is, unless Congress has "delegated" responsibility for "legislating" an alternative rule to the Court.

The delegated legislation approach to federal common law resembles the one advocated by Justice Scalia ${ }^{298}$ when applied to specific cases, although it focuses on the first, rather than the second, phase of the Court's task. The principal difference between the two is in the authoritativeness ascribed to state law when it is applied to federal questions. $^{289}$ Justice Scalia maintains that whenever state law is employed, it applies of its own force. The delegation view maintains that there are two circumstances under which the Court may make federal common law: 1) when there has been an express delegation by Congress, ${ }^{300}$ and 2) in particular areas in which Congress has indicated an intention to regulate an area of conduct, and the absence of a uniform federal common law "would threaten the smooth functioning of those . . processes that [the legislation] is chiefly designed to promote."301 Even in those areas in which Congress has specifically "delegated"

${ }^{295}$ See id. at 2762 (majority opinion).

${ }^{298}$ See id. at 2768 (Scalia, J., concurring).

297 See id. at 2762 (majority opinion).

288 Justice Scalia distinguishes this view from his own only at the metatheoretical level. He refers to this position as the second phase of the Court's history in using the "borrowing doctrine." See id. at 2771 (Scalia, J., concurring). Justice Scalia refers to this view as applying state statutes for the "wrong" reasons, whereas the reasons he attributes to the M'Cluny Court (i.e., state law applies of its own force) are the right ones. He does not discuss the more important distinction between the two views that we will emphasize in this section-namely, that state law applying of its own force has only the precedential value of the decisions of the state's highest court, whereas state law borrowed to serve as federal law has the precedential value of any other federal law through the supremacy clause.

298 See HART \& WECHSLER, supra note 28, at 767-70.

${ }^{300}$ See Texas Indus. v. Radcliffe Materials, 451 U.S. 630, 640 (1981) (Burger, C.J., writing for a unanimous court); supra notes 56-61 and accompanying text.

${ }^{301}$ UAW v. Hoosier Cardinal Corp., 383 U.S. 696, 702 (1966); see Texas Indus., 451 U.S. at 641 (Burger, C.J., writing for a unanimous court) ("[A]bsent some congressional authorization to formulate substantive rules of decision, federal common law exists only in [certain] narrow areas . . . ."); Wheeldin v. Wheeler, 373 U.S. 647, 651 (1963) (" $[\mathrm{W}] \mathrm{e}$ are not in the free-wheeling days antedating [Erie]. The instances where we have created federal common law are few and restricted." (citation omitted)); see also supra notes 62-66 and accompanying text. 
the authority to determine rules of decision, the Court may choose to borrow state law to serve federal purposes. ${ }^{302}$ This meta-legal view differs from the proposition that state law applies of its own force. In the statute of limitations context, an analysis based on the presumptive priority of state general limitations statutes would require the Court to apply state tolling rules, equitable doctrines, and so forth, as is required when the Court applies a state time bar to a state law cause of action. ${ }^{303}$ The Court has held that this is not its mode of analysis when the underlying cause of action is federal in origin. ${ }^{304}$ Rather, the Court borrows from state law "no more than necessary" for purposes of implementing the federal statute. ${ }^{305}$ Indeed, the Court need not apply state law at all when authority has been delegated to it to make such decisions: "[T]he Court has not mechanically applied a state statute of limitations simply because a limitations period is absent from the federal statute. . . 'Although state law is our primary guide in this area, it is not, to be sure, our exclusive guide." "306 This view portrays the federal structure of our system as creating at most a presumption that state law will be consulted when the Court must fill the interstices of a federal statute.

Because such an analysis requires the Court to consider what areas of conduct Congress intends to regulate in the substantive statute before it looks to state law, it may appear to afford somewhat less predictability. ${ }^{307}$ Accordingly, the Court has tried to specify those areas in

302 See Occidental Life Ins. Co. v. EEOC, 432 U.S. 355, 367 (1977). As Professor Mishkin stated:

[As to] problems which bear substantial relation to an established federal operation ... state law cannot govern of its own force; there must be competence in the federal judiciary to declare the governing law.

Such competence is essential to the effective implementation of the legislative powers committed to the national government by the Constitution.

Mishkin, supra note 68, at 799-800.

${ }_{303}$ See Walker v. Armco Steel Corp., 446 U.S. 740, 752-53 (1980).

304 See West v. Conrail, 107 S. Ct. 1538, 1541 \& n.4 (1987).

${ }^{305}$ See id. at 1542.

${ }^{308}$ Occidental Life, 432 U.S. at 367 (quoting Johnson v. Railway Express Agency, 421 U.S. 454, 465 (1975)).

307 Although one may be certain that the Court will look to state law, it may find that other considerations require a different rule of decision. See, e.g., Malley-Duff, 107 S. Ct. at 2765 (borrowing a time bar from another federal statute); DelCostello v. International Bhd. of Teamsters, 462 U.S. 151, 171-72 (1983) (borrowing a time bar from another section of the federal labor law). Moreover, if state law applied of its own force, the decisional law of the state would indicate the particular consequences of tolling rules, savings statutes, etc. When a limitation period is borrowed from the state, accrual and commencement are a matter of federal common law, although state tolling provisions may still be applied. See West, $107 \mathrm{~S}$. Ct. at 1541, 1542 n.6. On these and other "subsidiary issues" such as relation back, revival, survival, states' savings statutes, 
which common law making is to be expected. As stated by the Court in Texas Industries v. Radcliffe Materials, for example:

[A]bsent some congressional authorization to formulate substantive rules of decision, federal common law exists only in such narrow areas as those concerned with the rights and obligations of the United States, interstate and international disputes implicating the conflicting rights of States or our relations with foreign nations, and admiralty cases. In these instances, our federal system does not permit the controversy to be resolved under state law, either because the authority and duties of the United States as sovereign are intimately involved or because the interstate or international nature of the controversy makes it inappropriate for state law to control. ${ }^{308}$

However, the Lincoln Mills decision indicates that in the area of labor law, those matters which are integral to the primary conduct being regulated are implicitly included in the federal common law fold. ${ }^{309}$ In effect, the "congressional authorization" for annexing new ("implicitly delegated") areas is almost indistinguishable from traditional preemption analysis. ${ }^{310}$ As the court stated in O'Brien $v$. Western Union: "Congress having occupied the field by enacting a fairly comprehensive scheme of regulation, it seems clear that questions relating to [specific aspects of the regulated action] must be governed by uniform federal

borrowing statutes governing conflict of states' laws, and so forth, there is a relatively large body of federal common law that applies in determining when a federal court will borrow the state law governing the subsidiary issues. See generally Time Bars, supra note 76, at 1055-1105 (discussing the various subsidiary issues and federal precedents). It is not clear to what extent the recent West holding, i.e., that the Court borrows only "as much as is necessary," 107 S. Ct. at 1542, will affect this amorphous body of common law.

${ }^{308} 451$ U.S. 630,641 (1980) (Burger, C.J., writing for a unanimous court) (footnotes omitted).

${ }^{309}$ See Textile Workers Union v. Lincoln Mills, 353 U.S. 448, $456-57$ (1957).

310 See HaRT \& WeChSLER, supra note 28, at 767-68. The preemption of an entire area of law is arguably different from Justice Scalia's use of policy to preempt state law on a particular issue. See supra text accompanying note 229; of. Pacific Gas \& Elec. Co. v. State Energy Resources Conservation and Dev. Comm'n, 461 U.S. 190, 211-13 (1983) (In the context of nuclear-powered electricity generation, the federal government has preempted the safety and "nuclear" aspects of energy generation while states retain their traditional authority over such issues as determining the need for generating capacity, the type of facilities to be licensed, land use, and ratemaking.). However, the concurrence implies that if the preferred approach is unavailable, the "delegated legislation" view is favored over the Court's "statutory patchwork." See Malley-Duff, 107 S. Ct. at 2771 (Scalia, J., concurring) (ex proprio vigore approach "is the best approach to the question before us, and if a different historical practice had not intervened I would adhere to it." (emphasis added)). 
rules."311

As in the second phase of Justice Scalia's analysis, applying a traditional preemption inquiry to ascertain congressional intent concerning state statutes of limitations does not yield sensible guidelines for making federal common law (unless we regard the "intent" component as more than a convenient fiction). It intimates that the Court should consider congressional intent regarding the limitation for the substantive action, and state intent in enacting the general limitations statute. ${ }^{312}$ As the Court stated in Johnson v. Railway Express Agency:
Although any statute of limitations is necessarily arbitrary, the length of the period allowed for instituting suit inevitably reflects a value judgment concerning the point at which the interests in favor of protecting valid claims are outweighed by the interests in prohibiting the prosecution of stale ones. . . . In borrowing a state period of limitation for ap- plication to a federal cause of action, a federal court is rely- ing on the State's wisdom in setting a limit ... on ... closely analogous claim[s]. ${ }^{\mathbf{3 1 3}}$

This judgment about the interests at stake partakes of both the policies governing the creation of the right, and the social and institutional concerns regarding the provision of fair and effective judicial remedies for that right. ${ }^{314}$

Both the majority and concurring opinions in Malley-Duff referred to congressional intent regarding state statutes of limitation. ${ }^{\mathbf{3 1 5}}$ Justice Scalia stated their shared position: "[A]fter a century and a half of the Court's reacting to congressional silence by applying state statutes . . . it is reasonable to say that such a result is what Congress must expect, and hence intend, by its silence." ${ }^{\text {"16 }}$ However, this inference merely re-

311 O'Brien v. Western Union Tel. Co., 113 F.2d 539, 541 (1st Cir. 1940).

312 This is the source of the doctrine that state law may not be applied if it discriminates against vindication of the federal right, whether discrimination is actual or de facto. See, e.g., Occidental Life Ins. Co. v. EEOC, 432 U.S. 355, 368-69 (1977) (refusing to apply a state limitations period that would frustrate the policy of federal law and thus be inconsistent with congressional intent); Van Horn v. Lukhard, 392 F. Supp. 384, 389 (E.D. Va. 1975) (Virginia statute applicable only to $\S 1983$ actions found to create an "invidious and unwarranted discrimination" against the federal cause of action). See generally Time Bars, supra note 76, at 1046-55 (discussing the forms of discrimination against federal rights generally found to be undue burdens).

${ }^{313} 421$ U.S. 454, 463-64 (1975).

334 See supra notes 88-94 and accompanying text.

316 See Malley-Duff, 107 S. Ct. at 2762 (O'Connor, J, writing for the Court); id. at 2771 (Scalia, J., concurring).

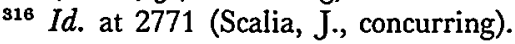


labels the Court's legitimate meta-legal concerns ${ }^{317}$ with the exculpating name of "congressional intent." 318 While this allows the Court a convenient and seemingly dispositive reason for the choices it made in deciding the case, this reason bears no necessary relationship to actual legislative processes, nor does it require the Gourt effectively to account for its reasoning.

Consider, for example, the implausible idea that Congress intended that the Court rely on the states' wisdom in setting statutory limits. ${ }^{319}$ It is highly unlikely that the legislature specifically avoided enacting a substantive time bar in order to rely on the wisdom of the states in specifying what almost everyone agrees is a somewhat arbitrary period of time..$^{320}$ Indeed, the legislative history of civil RICO reveals that the limitations gap probably resulted from Congress' political maneuvering on unrelated issues that might have prevented the entire program from passing. ${ }^{321}$ No matter how important a time bar is to

31 Examples of legitimate concerns that might possibly motivate the Court include the relative authority of state and federal rules applied to federal causes of action, maintaining a coherent federalism in our dualistic legal system, and balancing the equities of remedying rights violations and providing repose.

318 See Curtis, A Better Theory of Legal Interpretation, 3 VAND. L. REv. 407, 415 (1950) (discussing the Court's quest for legislative purpose: "Better that the courts should set their decisions up against the possibility of correction than make them under the shadow of a fiction which amounts to a denial of any responsibility for the result.").

${ }^{319}$ As Judge Learned Hand observed:

When we ask what Congress 'intended,' usually there can be no answer, if what we mean is what any person or group of persons actually had in mind. Flinch as we may, what we do, and must do, is to project ourselves, as best we can, into the position of those who uttered the words, and to impute to them how they would have dealt with the concrete occasion.

United States v. Klinger, 199 F.2d 645, 648 (2d Cir. 1952), affd, 345 U.S. 979 (1953). ${ }^{320}$ Judge Friendly maintained that "selection of a period of years [is not] the kind of thing judges do . ..." Moviecolor Ltd. v. Eastman Kodak Co., 288 F.2d 80, 83 (2d Cir. 1961). Presumably, this is because the duration is thought to be a policy judgment of the sort that is best left to the legislature. But apart from periods that are too long to provide meaningful repose, or too short to allow vindication of rights because of the time required for the administrative and judicial systems to function, there are almost no objective reasons for preferring one period as opposed to another.

At its worst, the myth of legislative balancing of equities regarding these periods leads the Court to create amusing reasons for choosing a four-year period as opposed to a five-year period. See, e.g., Malley-Duff, 107 S. Ct. at 2767 (Clayton Act's four-year period is preferable because "the 5-year statute of limitations for criminal RICO actions does not reflect any congressional balancing of the competing equities unique to civil RICO actions or, indeed, any other federal civil remedy."). But see supra notes 168-69 and accompanying text (discussing the time periods recommended by the ABA Task Force, and debated by the Congress). While the Court's reasons for its choice may be perfectly legitimate (e.g., Court precedents specifying an analogy between the federal statute and the state limitation period), it is somewhat bizarre to attribute them either to congressional intent in enacting the substantive statute, or a state legislature's intent in enacting the general limitations statute.

${ }^{321}$ See supra text accompanying notes 158-61. 
private vindication of the rights being created, a reasonable legislator will not insist on adding a limitations period simply for the sake of completeness, when the floor activity required to do so will provide opponents with an opportunity to amend the legislation into a politically or legally unacceptable form. Thus, while it may be reasonable to assume that a history of the Court's willingness to imply suitable statutes of limitations (whatever their source) makes it possible for members to attach little value to actively debating the niceties of a time bar for a particular cause of action, that is not the same as saying that congressional silence supports a presumption that Congress intends that state limitations periods apply.

In addition to the fictions about congressional and state intent that this view engenders, it raises troubling separation of powers concerns. The notion that Gongress "delegates" responsibility for legislating in particular substantive areas may be appropriate for understanding its relations with administrative agencies, ${ }^{322}$ but it does not provide a desirable model for the relations among coequal branches of the government. To say that Congress delegates responsibility for details to the judiciary in particular substantive areas of lawmaking is to confound the notion of jurisdictional grants by Congress with the judiciary's own constitutional power under article III. ${ }^{323}$ The courts are responsible for interpreting and applying the federal law-including fashioning remedial details where Congress has not spoken. ${ }^{324}$

${ }^{322}$ See T. Lowi, The End of Liberalism 298-99 (1969). Compare K. Davis, DisCRETIONARY JUSTICE 48-51 (1969) (discussing delegation as a legislative inevitability) with Wright, Beyond Discretionary Justice (Book Review), 81 YALE L.J. 575, 585 (1972) ("[T]he arguments for broad delegation rest on the illusion that problems are solved by conflict avoidance.").

Congressional delegation of adjudicative power to agencies raises issues that are not implicated in this approach to federal common law. See, e.g., Commodity Futures Trading Comm'n v. Schor, 106 S. Ct. 3245, 3256 (1986) (stating that the key to ensuring separation of powers is preserving essential article III functions in the courts). Indeed, the separation of powers problem here is the antithesis of that raised by agency delegations (i.e., Congress making inroads on the courts' constitutionally-mandated area of responsibility). What is problematic about the delegated-legislation view of federal common law is the Court's attribution of authority for its own common law making power to the legislature. In effect, by denying that its own place in our system of government conveys power and responsibility for implementing statutory schemes by making federal common law, the Court diminishes its efficacy as a check on legislative or executive excesses.

${ }^{323}$ See generally 13 C. Wright, A. Miller, \& E. Cooper, Federal Practice and Procedure: Jurisdiction and Related MatTers, $\S 3522$ (2d ed. 1984) (discussing the relation between article III and congressional statutes that creates the jurisdiction of the federal courts).

324 See, e.g., Board of County Comm'rs v. United States, 308 U.S. 343, 352-53 (1939) (remedial details left to judicial implication). 


\section{Institutional Confrontation}

An approach to federal common law based on institutional confrontation makes the Justices' meta-legal views of the Court's role as an institutional guardian the focal point of its lawmaking. When institutional guardianship is used in an adversarial manner, the Court's preferred theory of institutional relations provides a basis for making law that conveys some message to the legislature or executive. The particular resolution of the dispute that derives from this approach is not significant, so long as the correct institutional message is conveyed. ${ }^{\mathbf{3 2 5}}$

The legitimacy of a confrontational approach is rooted in a long history of tensions among the branches of the federal government as well as between state and national governments, and an even longer history of tensions between judge-made common law and statutory law. Westen and Lehman ${ }^{328}$ suggest that this confrontational vision of common law may be traced to Lord Coke's dictum in Dr. Bonham's Case, ${ }^{327}$ which stated that "when an Act of Parliament is against common right and reason, or repugnant, or impossible to be performed, the common law will controul it, and adjudge such Act to be void .328 Although judicial review of a statute's constitutionality may be a related idea, in our constitutional system the common law does not govern congressional enactments. Nevertheless, the vague notion that common law making is a force for judicial hegemony recurs in criticisms of judicial activism. ${ }^{328}$

Contemporary apprehension about the power of legal interpretation has juxtaposed the judiciary not only with Congress and the Executive, but more directly with the states. ${ }^{330}$ Hence, the current federal common law controversy is more openly linked to the federalism concerns it raises than to separation of powers issues. ${ }^{331}$ There are several

${ }^{328}$ See Weisberg, supra note 143, at 244 ("statutory interpretation is a means of 'inducing confrontation with the legislature" " (quoting Wellington \& Albert, supra note 144, at 1566)); supra notes 135-44 and accompanying text.

328 See Westen \& Lehman, supra note 11, at 331 \& n.60.

32777 Eng. Rep. 646 (K.B. 1610).

328 Id. at 652.

329 In our own history, this formless fear is deeply rooted in the politics that shaped our institutions. See Jay, supra note 25, at 1003; see also 2 G. Haskins \& H. Johnson, History of the Supreme Court of THE UnIted STATes 50-73 (1981) (summarizing Federalist-Republican conflicts over Court's power).

330 See, e.g., P. KurLaND, supra note 205, at 21-97 (arguing that animus toward the Warren Court prompted congressional efforts to restrain the judiciary by both asserting legislative and executive preeminence as well as calling for states' rights).

${ }^{331}$ See Field, supra note 14, at 932-34. However, critiques of the Warren Court emphasize separation of powers as well as federalism. See, e.g., P. KuRLAND, supra note 205, at 21-97. Separation of powers issues may become more dominant if the form of judicial activism discussed hereafter, see infra text accompanying note 337, material- 
features of the Malley-Duff concurrence which suggest that it drew from such a confrontational vision of the Court's institutional guardianship. Justice Scalia's favored practice involves deference to state law, rather than making federal common law. ${ }^{\mathbf{3} 2}$ But he merely asserted the facial applicability of states' general statutes of limitations, and the selfevident power of states to limit federal causes of action unless explicitly preempted by Congress. ${ }^{333}$

Justice Scalia concluded that Malley-Duff's action was not barred because there should be no statute of limitations on civil RICO actions. $\mathrm{He}$ intimated that such an option evinces "judicial restraint" by not legislating where Congress has not spoken. However, because such a decision is itself federal common law, it provides a rule of decision for future cases until Congress enacts a limitations period, or the Court reverses itself.

If the Court had adopted Justice Scalia's recommendation, it would have been making a very clear policy statement. Indeed, it would have implemented a policy inherently destructive of the purposes of civil RICO and one that would have overwhelmed federal court dockets. 'The treble damages provision of civil RICO is very popular with plaintiffs. ${ }^{334}$ Exempting it from a time bar would likely enhance its popularity. Not only would courts have to sort through RICO claims that serve primarily to enhance the potential recovery of claimants; courts would also have to identify and decide what to do about those claims that would have been time barred had they not included a RICO count. Such an action by the Court would have established a policy in which "scarce resources must be dissipated by useless litigation on collateral matters." 335

It is unlikely that Justice Scalia seriously intended to give prospective RICO plaintiffs such an overweening advantage, or to clog the federal courts with plaintiffs taking their chances in the RICO treble dam-

izes as an explicit strategy used by the Court to look after its constitutionally-mandated tasks. See G. Calabresi, supra note 135 , at 146-62.

${ }^{332}$ See supra notes $222-40$ and accompanying text. Note that while the Court has often "borrowed" a state rule of decision as a convenient "rule of thumb" when making federal common law, see DelCostello v. International Bhd. of Teamsters, 462 U.S. 151, 158 \& n.12 (1983), this is not what Justice Scalia intends. To the contrary, he argues that the "best approach" involves no borrowing, but only a preemption check. See Malley-Duff, $107 \mathrm{~S}$. Ct. at 2771 (Scalia, J., concurring). If the federal statute does not require the preemption of state law, state law applies of its own force. See id.; supra notes 222-33 and accompanying text.

${ }^{333}$ See Malley-Duff, 107 S. Ct. at 2768 (Scalia, J., concurring). This conclusion does not derive from an analysis of either the federal or state law. See supra notes 22225 and accompanying text.

334 See supra text accompanying notes 162-63.

33s Wilson v. Garcia, 471 U.S. 261, 275 (1985). 
ages lottery. Rather, it is more likely that he has borrowed a page from Justice Frankfurter's book. As Calabresi notes, "Justice Frankfurter explicitly justified a narrow, harsh interpretation of those laws on the ground that such a reading would break the log jam of interests and force the legislative hand." ${ }^{336}$ If the comparison is apt, Justice Scalia would have the Court engage in a serious spate of judicial activism; for while he stated that he refused to usurp congressional intent by "legislating" a time bar based on the Court's analysis of the RICO statute, he was perfectly willing to dictate Congress's legislative agenda by undermining the program established by the statute. ${ }^{337}$

Besides fostering inattention to the dispute that the Court had been asked to resolve, one particularly troubling side effect of this form of judicial activism is that it renders superfluous the Court's language and reasoning. If the sole purpose of the opinion was to manipulate Congress into changing its agenda to suit the Court, then the tests, legal doctrine, precepts, and interpretations promulgated by the Court have no precedential value. The Court's activities are then no more than strategic moves in the present judicial confrontation with Congress, for which the parties' dispute has provided a convenient vehicle. Over the long run, such a strategy would make fools of those who look for meaning in precedent, and, in passing, make prophets of the proponents of Critical Legal Studies. ${ }^{\mathbf{3 3}}$

\section{E. Implications for Federal Common Law}

With the exception of the first model, each of the analyses of the Court's federal common law power distorted the subject matter of the dispute in our statute of limitations case. The overarching metatheory of the web of law requires us to slip in an anomalous category of exceptions in order to maintain the purity of the viewpoint itself. The delegation model offers a way to accommodate both an overarching view and categories of exceptions, if we accept a set of fixed categories. But the price is a confusion of the Court's constitutionally mandated responsibility for its tasks with its power vis-à-vis Congress. The confrontational model elevates these power relations to the forefront of the Court's deliberation. Whether referring to the Court's relation to state courts, or its relation to Congress, this model transforms the litigants'

${ }^{336}$ G. Calabresi, supra note 135 , at 34 \& n.14.

s37 Then-Justice Rehnquist also declared himself willing to use this adversarial tactic in his concurrence in Cannon v. University of Chicago, 441 U.S. 677, 718 (1979).

${ }_{338}$ See, e.g., R. UNGER, supra note 15, at 8-11 (indicating that what others sanctify as the "rule of law" can be reduced to reciprocal role and power relations). 
dispute into an experimental paradigm for testing and proving the matter of "real" interest to the Court.

The advantage of the first, "pragmatic" model is that it allows the Court to consider each of the other meta-legal issues in relation to the substantive dispute it is being asked to adjudicate. That is, in "characterizing" the claim in terms of the substantive right created by Congress, the Court establishes the boundaries of its inquiry in relation to state law. ${ }^{339}$ Its power to adjudicate the dispute does not exceed the scope of the substantive statute, but within those borders, the Court has the power to ascertain appropriate rules of decision. In the discretion phase of its analysis, the Court is free to consider its own precedents and doctrines for approaching this type of issue, the policy interests expressed by the substantive statute, the institutional and social interests served by statutes of limitations, the equities of the factual situation as found by the trial court, and conflicting state interests in the subject matter.

\section{ConCLUSION}

Perhaps because "missing" time limitations áre simultaneously so arbitrary when considered in and of themselves, and yet so dispositive within the context of a particular dispute, they provide a useful way to examine the impact of the Justices' meta-legal concerns. Important substantive rights are at stake, but they are not correlated with the policies embodied by statutes of limitations; significant institutional concerns are raised by the policy of limiting actions, but decisions that do not integrate these concerns in resolving the dispute reveal underlying agendas that encompass only fragments of what is at stake.

Our examination of four different meta-legal orientations toward federal common law making reveals that the Court's orientation is multifaceted and shifting. Our purpose in identifying the meta-legal underpinnings of the Justices' opinions is neither to excoriate them in yet another frenzied quest for "objectivity," nor to indulge in waves of doubt regarding the efficacy and purpose of the legal enterprise. Contemporary America is sophisticated enough to recognize that donning the robe and ascending to the bench does not purge a judge's mind-like Justice's blindfold-of the values and beliefs she holds as a

3s9 This analysis would be more extensive than that proffered by the Court in Malley-Duff. The Court seems to have allowed the "delegated legislation" precedents of previous statutes of limitation cases to attenuate the more complete "power analysis" required in making federal common law. See supra notes 295-97 and accompanying text. 
member of this society. Yet the metaphor of blind Justice represents our confidence that by eschewing political rhetoric, and discoursing in the language of legal doctrine, precedent, and statutory and constitutional law, our courts will achieve a fair resolution of citizens' cases and controversies. ${ }^{340}$

That is why it is so important to make ourselves aware of how legitimate concerns with legal theories and institutional relations affect the Justices' deliberations when we ask them to resolve a dispute. The objective is not to expunge these over-arching views-to the contrary they are useful, if imperfect, tools for analyzing complex problems. The objective is to be aware that it is the individual's choice to use or not to use a particular tool as the situation requires. Becoming aware of the features of our own thinking that shape the law and the institutions that affect our lives is the cornerstone of a contemporary approach to human problems. ${ }^{341}$

Such a heightened awareness of our own metatheoretical vantage point, like that of a street-wise urbanite walking a country lane, contrasts markedly with analyses of legal theory in a simpler time. Consider the following statement of a legal theory and the author's reasons for espousing it:

The law which governs daily living in the United States is a single system of law: it speaks in relation to any particular question with only one ultimately authoritative voice, however difficult it may be on occasion to discern in advance which of two or more conflicting voices really carries authority. In the long run and in the large, this must be so. People repeatedly subjected, like Pavlov's dogs, to two or more inconsistent sets of directions, without means of resolving the inconsistencies, could not fail in the end to react as the dogs did. The society, collectively, would suffer a nervous breakdown. ${ }^{342}$

Discussions of this well-known version of the "seamless web" approach

310 See, e.g., R. Dworkin, Law's EMPIRE 164-66 (1986) (discussing integrity, fairness, and justice as the foundations of a detached rule of law).

341 See, e.g., H. Gadamer, Philosophical Hermeneutics 9 (1976) ("It is not so much our judgments as it is our prejudices that constitute our being. . . . Prejudices are ... simply conditions whereby we experience something . . . (footnote omitted)); J. Habermas, KNowledge and Human INTERests 181 (1971) (One "can arrive at objectivity to the extent that the understanding subject learns, through the communicative appropriation of alien objectivations, to comprehend itself in its own self-formative process.").

${ }^{342}$ Hart, The Relations Between State and Federal Law, 54 Colum. L. Rev. 489,489 (1954). 
typically analyze the first sentence, the statement of the metatheoretical viewpoint. It expresses a legitimate concern that law be a coherent system that speaks with a single authoritative voice. ${ }^{343}$

We, too, have been concerned with some of the contemporary doctrines that derive from this view. But the more revealing part of the statement, for our purposes, is the latter half. In keeping with this viewpoint's concern about the legitimacy of authority, the statement provides us with its own understanding of the source for the authority of the viewpoint itself-it "must be so." The author is telling us that he is arguing from necessity-not logic, precedent, or aesthetics, but the psychological necessity of consistency in our social system. And the Armageddon he envisions as the consequence of abandoning this viewpoint provides a powerful incentive for agreement.

What is problematic about this argument is that it does not accommodate the realities of the disputes that actually arise under the law. While consistency and absolute predictability might make many things easier to accomplish, life in a complex society does not afford us this luxury. Differing roles and duties are in conflict, people in different positions of authority offer conflicting advice, and our system of government is built on the separation and inevitable disparity of the executive, legislative, and judicial branches of the national government, and of the national and state governments.

The majority of individuals do not have nervous breakdowns under these conditions. Indeed, many people learn at an early age to exploit the inconsistencies of authority to their own advantage. In a very real sense, what results when an authority system is unable to maintain coherence and integrity is either the usurpation of its power, or a collective disregard for its pronouncements. Seen in this way, the task of nurturing our federal system in a complex society is not simply a matter of establishing a resolute and predictable authority. It requires awareness and communication to allow legal actors to choose intelligently a particular solution to a specific problem, rather than to evade responsibility for the consequences by retreating to metatheoretical views that may have been useful in other contexts.

[W]ithin the limits lying between the command of statutes on the one hand and the restraints of precedents and doctrines, by common consent regarded as binding, on the other, the judge has liberty of choice of the rule which he applies, and ... his choice will rightly depend upon the relative weights

34s Cf. R. Dworkin, supra note 340 , at $228-54$ (discussing his "chain novel" approach to a conception of law as integrity). 
of the social and economic advantages which will finally turn the scales of judgment in favor of one rule rather than another. Within this area he performs essentially the function of the legislator, and in a real sense makes law..$^{\mathbf{3 4}}$

344 Stone, The Common Law in the United States, 50 HARv. L. Rev. 4, 20 (1936). 
